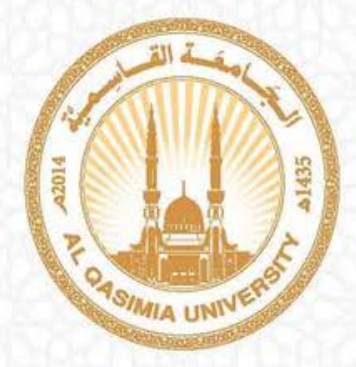

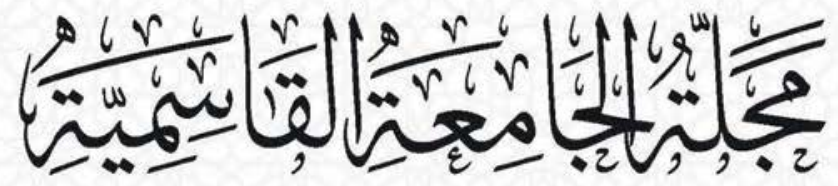

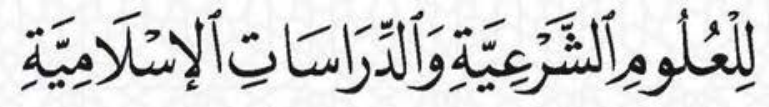

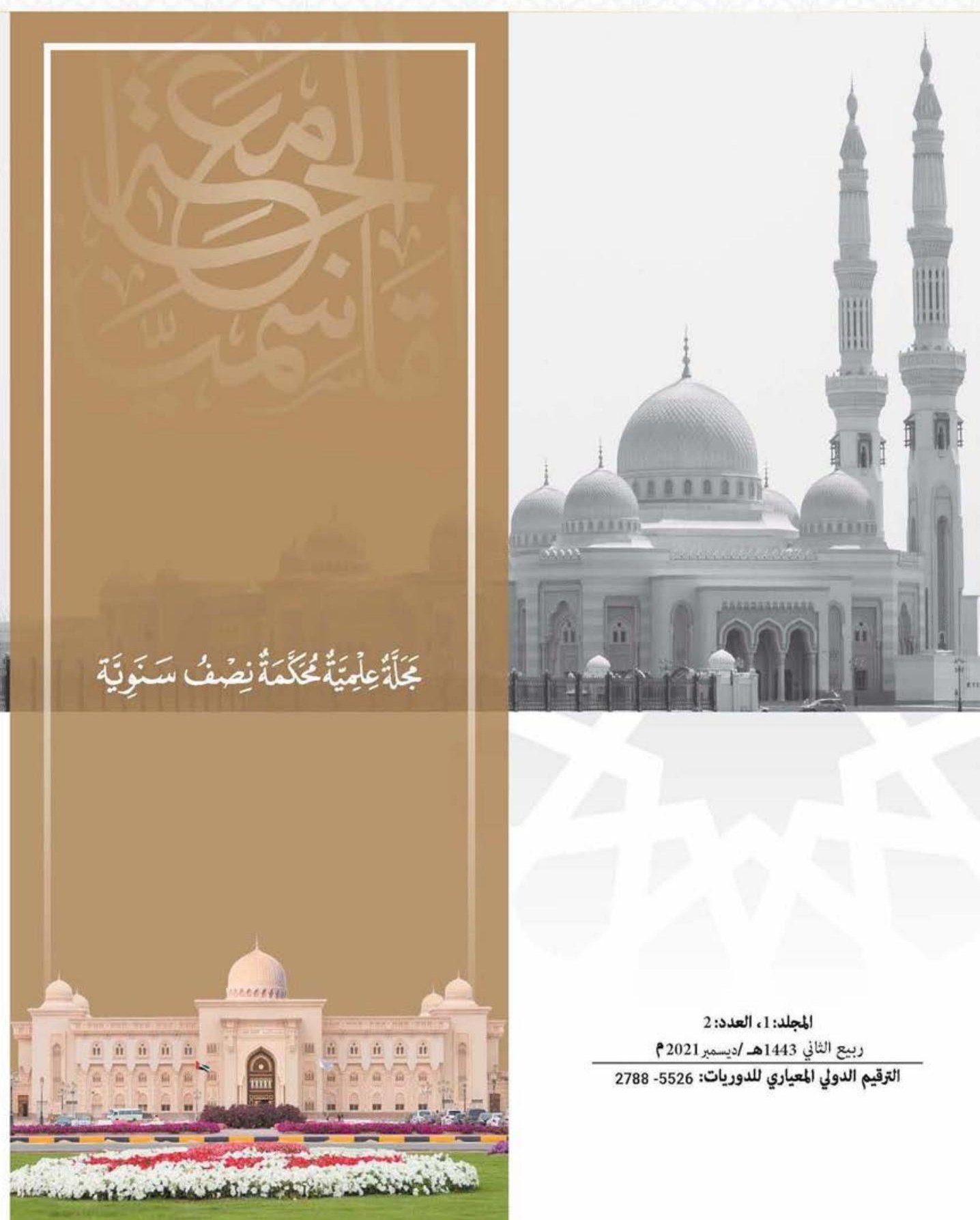




\section{التأصيل الشرعي لسلطة ولي الأمر في الإلزام بالحجر الصحي}

Islamic Evidence of the Ruler’s Authority to Impose Quarantine ${ }^{1}$

$$
\text { يوسف أحمد عمر }
$$

جامعة محمد بن زايد للعلوم الإنسانية، الإمارات العربية المتحدة

Yousif Ahmed Omar

Mohammed bin Zayed University for Humanities, UAE

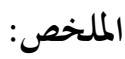

يهدف البحث إلى بيان التأصسيل الشـرعي للحجر الصـحي في الحدد من انتشـار الأوبئة والأمراض المعـديـة؛ وذلكك لأن الـدول لجأت لتطبيق إجراءات احترازيـة تقيـد الحريـة الشخصية كالحجر الصحي؛ لمقاومة الوباء السريع الانتشار المسمى بفيروس كوفيد 19، فبين الباحث التأصـيل الشــرعي للحجر الصــحي، ومدى سـلطة ولي الأمر في الإلزام بالحجر الصحي، وإثبات مشروعية عقاب المخالفين للحجر الصحي. فانتظم البحث في ثلاثة مباحث: ناقش الباحث في المبحث الأول عن تعريف الحجر الصــــي ونشــأته

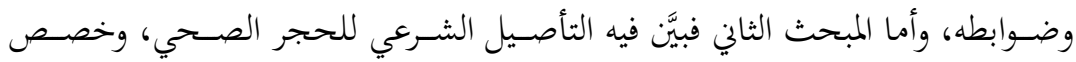

\section{Abstract}

المبحث الثالث للتأصيل الشرعي لسلطة ولي الأمر في الإلزام بالحجر الصحي.

The research aims to demonstrate Islamic evidence of quarantine in limiting the spread of epidemics and infectious diseases because countries around the globe have resorted to applying precautionary measures, such as quarantine, that restrict personal freedom in order to control the rapidly spreading COVID-19. The researcher aims to prove the legitimacy of penalizing quarantine violators. The research is divided into three sections: the first section elaborates on the definition of

\footnotetext{
${ }^{1}$ Article received: August 2021; article accepted: October 2021
} 
quarantine, its origin and rules. The second one details the Islamic evidence on the validity of quarantine. The third section is devoted to the Islamic evidence of the guardian's authority to impose quarantine.

الكلمات الدالة: الحجر الصحي-الأوبئة-التأصيل الشرعي-سلطة ولي الأمر

Key Words: Quarantine - Plagues- Islamic Evidence - the Ruler's Authority

الحمد لله رب العالمين والصلاة والسـلام على نبينا محمد، وعلى آله وصحبه ومن

$$
\text { تبع هلديه، وبعل: }
$$

يمر العالم الإنساني بأزمة كبرى، ومنحى صعب من تاريخه، ومعضلة بشرية حقيقية

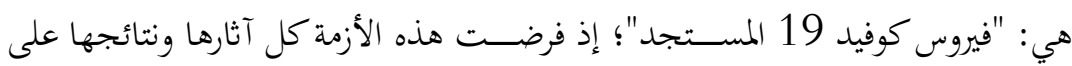
العالم، فهي تحد إنسـاني حقيقي، وظرف عصسيب يستلزم من البشـية جمعاء قيم التعاون

والتضامن، وقيم الالتزام والقانون لتجاوز هذه المرحلة(1).

نعم إنه فيروس كورونا المستجد الموسوم بــ(كوفيد-19)، الذي ظهر في جمهورية

الصــين الشـعبية وفي مدينة ووهان بالتحديد، وكان ظهوره أواخر عام (2019)م، وهو

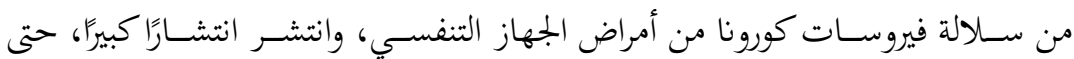

فقدت الســيطرة عليه، مما جعل منظمة الصــحة العالمية تعلن بأنه جائحة عالمية، حيث

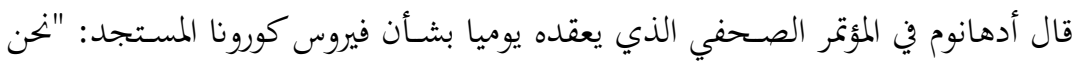
لم نشهـد من قبل جائحة يسببها فيروس من فيروسات كورونا، هذه أول جائحة يسببها

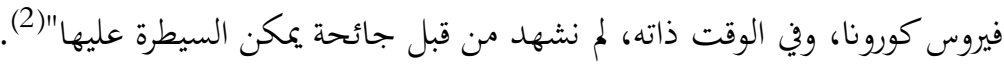

(1) الظاهري، د.خليفة، المدي النبوي في التعامل مع الأوبئة، بحث منشور ضمن كتاب "روح وريحان" الصادر من جامعة محمد

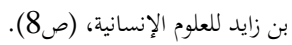

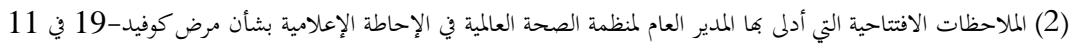

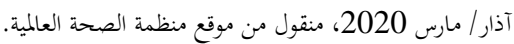

https://www.who.int/ar/director-general/speeches/detail/who-director-generals-opening-remarks-at-the-media-briefing-on-covid-19---11-march-2020 
وأيقن العالمُ خطورة هذه الجائحة، مما جعل الدول تتخذ كثيرا من الإجراءات

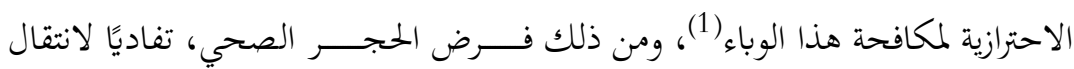

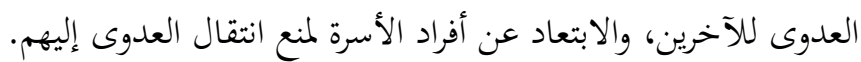

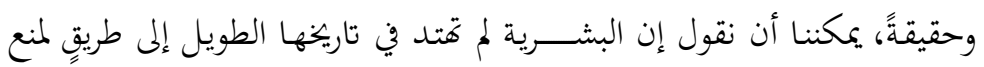

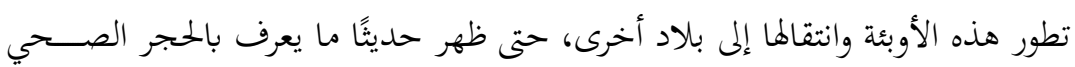
بصورته الحديثة، وإن كان أصله واردا في السنة النبوية(2). فما التأصيل الشرعي للحجر الصحي زمن الوباء؟ وهل يعارض ذلك مبدأ الحرية

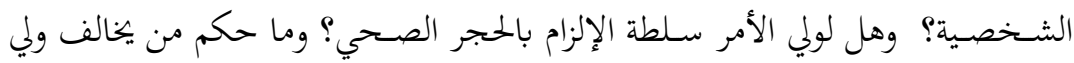

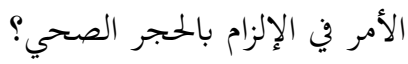
هذا ما سنجيب عليه في هذه الدراسة، إن شاء الله تعالى، و الله الموفق.

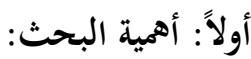
تظهر أهمية البحث في: 1-بيان دور الحجر الصحي في الحدد من انتشار الأوبئة والأمراض المعدية. 2-التأصيل الشرعي للحجر الصحي زمن الأوبئة.

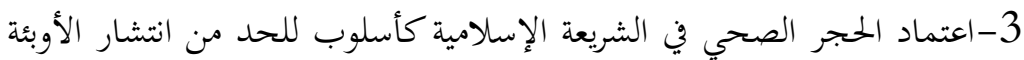

\section{المعدية.}

4-بيان سلطة ولي الأمر في الإلزام بالحجر الصحي.

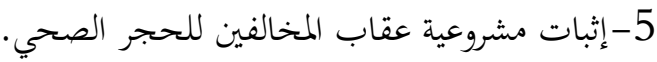

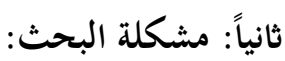

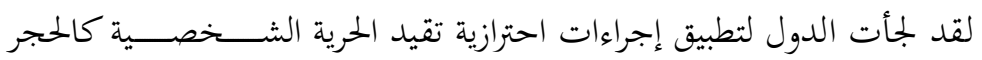

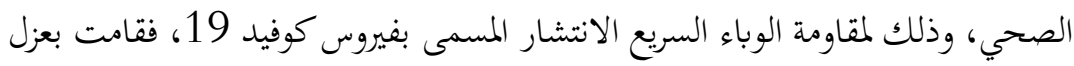

(1) توصيات الندوة الطبية الفقهية الثانية بعنوان: "فيووس كورونا المستجد (كوفيد19) وما يتعلق به من معالجات طبية وأحكام

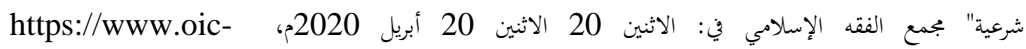
oci.org/topic/?t_id=23343\&t_ref=13985\&lan=ar (2) المسلم، صالح عمد، الحجر الصحي وأحكامه الفقهية، (ص25). 
المصـاب أو المشتبه به عن الأشـخاص الأصسحاء في أماكن مهيأة لذلك، وكذلك فرض

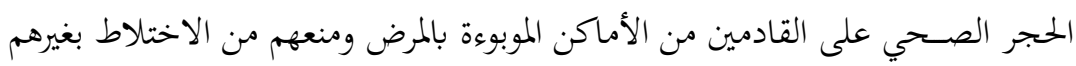
لضمانة عدم انتشار العدوى.

فمشكلة البحث تتمحور في مشـروعية الحجر الصسحي؟ وهل لولي الأمر سلطة الصدان

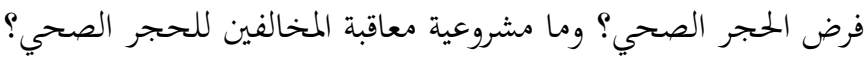
ثالثاً: أسباب اختيار الموضوع: 1- تفشي وباء فيروس كورونا المستجد "كوفيد 19" وتسببه في وفاة الكثير من البشر الموضر

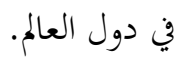
2-تبني الدول للحجر الصحي كأسلوب للحد من انتشار وباء فيروس كورونا المستجد و تأصيل ذلك شرعا. 3- تأصيل سلطة ولي الأمر كنوع من أحكام السياسة الشرعية لفرض الحجر الصحي، لمكيل ومعاقبة المخالفين. 4-بيان عظمة الشريعة الإسلامية؛ وصلاحيتها لكل زمان ومكان. رابعاً: الدراسات السابقة: اطلعت على بجموعة من الدراسـات التي بحثت مسألة الإجراءات الاحترازية التي

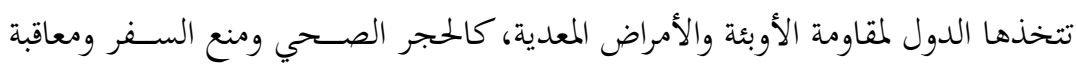
المخالفين لهذه القرارات، ومن هذه الدراسات:

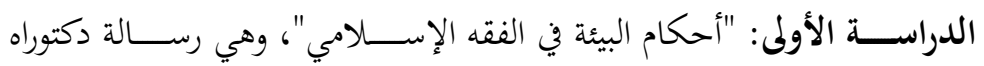

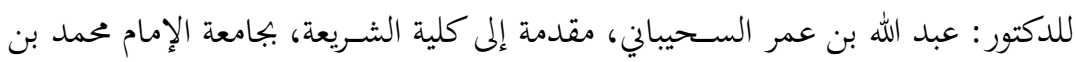

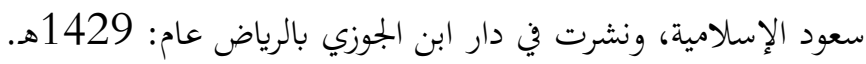

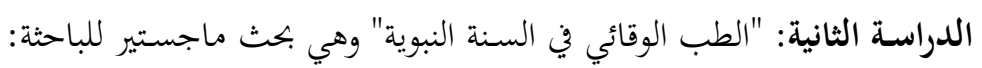

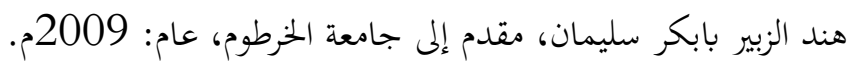

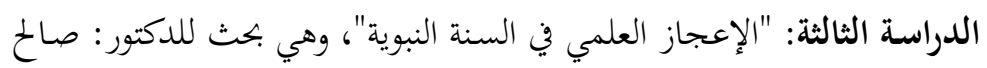

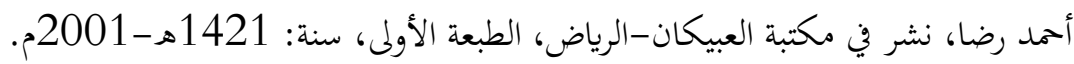


الدراســة الرابعة: "أحكام الحجر الصــحي زمن الأوبئة"، وهي بحث للدكتور:

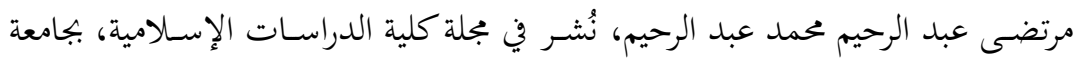

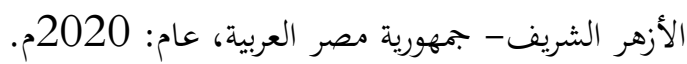

الدراسـة الخامسـة: "الحجر الصـحي بين الضـرورة والآثار" وهي بحث للدكتورة:

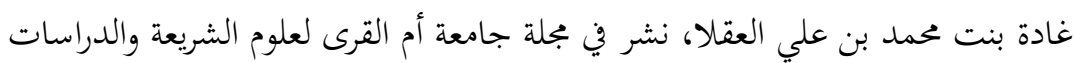
الإسلامية، عام: 1442هـ/2020.

ولا يستغني الباحث المتأخر عن المتقدم، فقد سـبقوه في العلم والفضـل، ووجهة

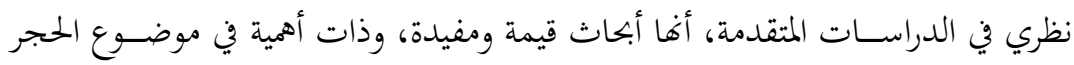

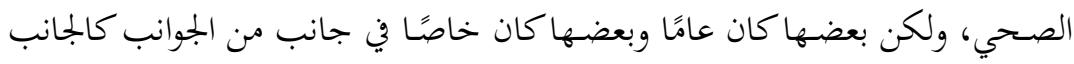

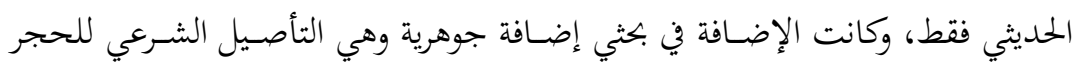

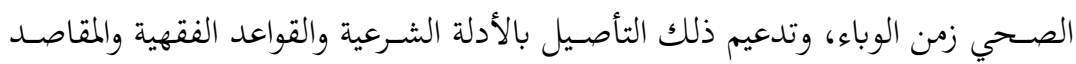

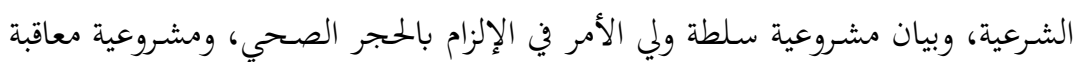

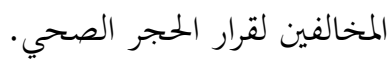

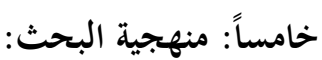

لقد تنوع منهجي في البحث بين المنهج الاســتقرائي، بجمع المعلومات وترتيبها

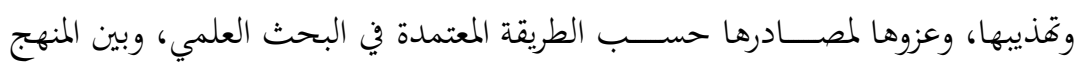
المقارن، بمقارنة الأقوال مع بعضها البعض، وبين المنهج التحليلي، بتحليل الأدلة، ومحاولة

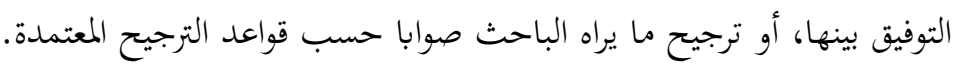

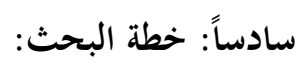

يتكون هذا البحث من: مقدمة، وثلاثة مباحث، وخاتمة.

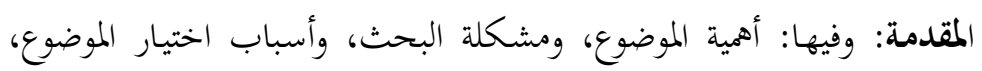

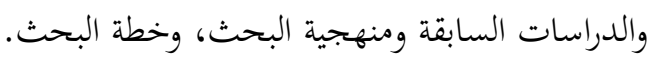
المبحث الأول: تعريف الحجر الصحي ونشأته وضوابطه. المطلب الأول: تعريف الحجر الصحي. تعريف الحجر الصحي ون 
يوسف أمد عمر

$$
\begin{aligned}
& \text { المطلب الثاني: نشأة الحجر الصحي. } \\
& \text { المطلب الثالث: ضوابط الحجر الصحي في دولة الإمارات. } \\
& \text { المبحث الثاني: التأصيل الشرعي للحجر الصحي. }
\end{aligned}
$$

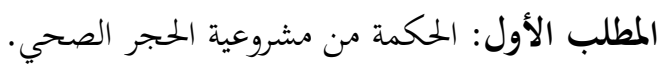

$$
\begin{aligned}
& \text { المطلب الثاني: مشروعية الحجر الصحي. المطي. } \\
& \text { المطلب الثالث: الحكم التكليفي للحجر الصحي. }
\end{aligned}
$$

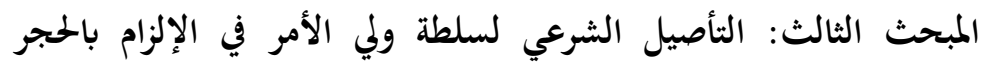

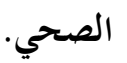

المطلب الأول: مشروعية إلزام ولي الأمر بالحجر الصحي.

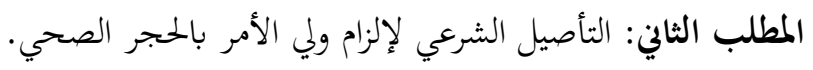

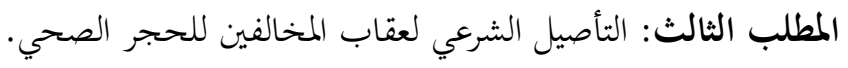

$$
\text { الخاتمة: وتتضمن أهم نتائج البحث وتوصياته. }
$$




\section{المبحث الأول: تعريف الحجر الصحي ونشأته وضوابطه. \\ المطلب الأول: تعريف الحجر الصحي.}

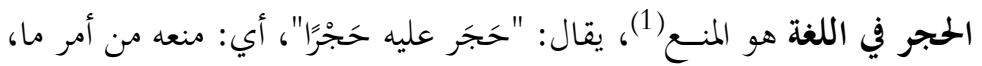

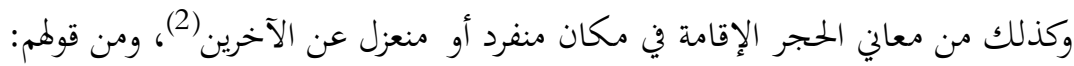

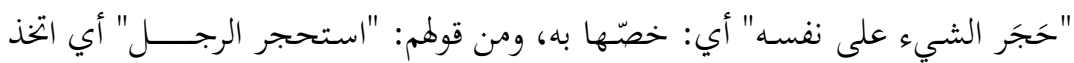

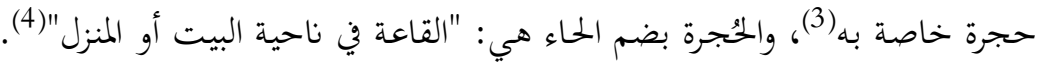

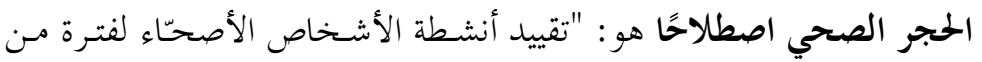

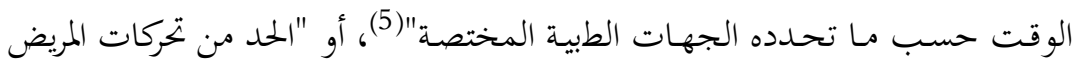

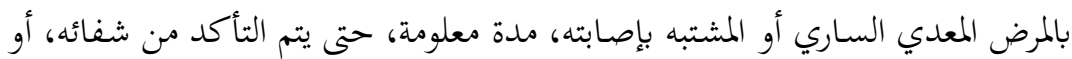

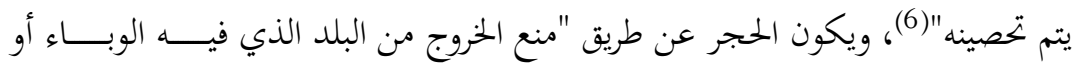

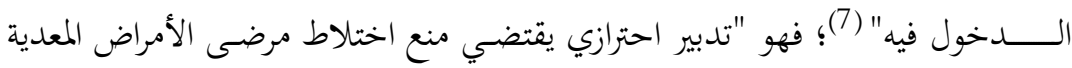

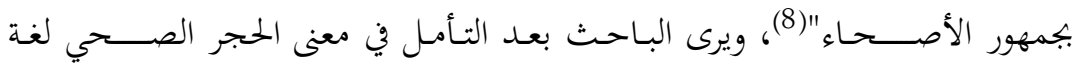

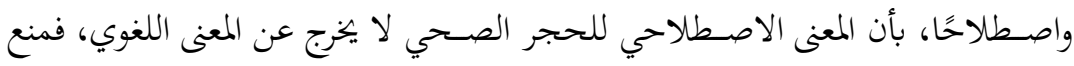
(1) ابن فارس، أبو الحسين أحمد بن زكريا، مقاييس اللغة، (ت 90بهـ)، تحقيق: عبدالسلام هارون، دار الفكر بيروت،

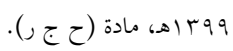
(2) الأزهري، أبو منصور محمد بن أحمد، تحذيب اللغة، (ت . . آهـ)، تحقيق: إبراهيم الأبياري، دار الكتاب العربي، بيروت

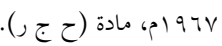

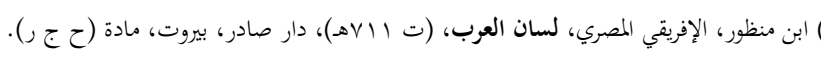

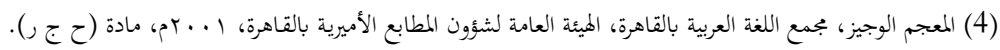
(5) البوابة الرسمية لحكومة دولة الإمارات العربية المتحدة:

https://u.ae/ar-AE/information-and-services/justice-safety-and-thelaw/handling-the-covid-19-outbreak/quarantining-to-fight-covid-19

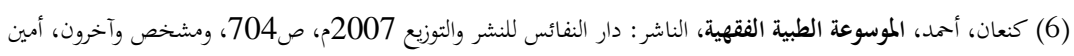

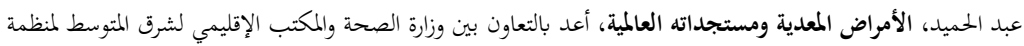

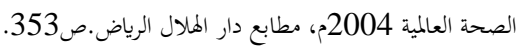

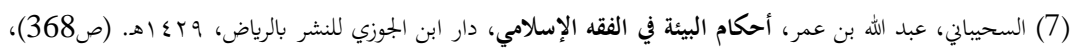

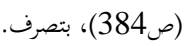

(8) كنعان، أمد، الموسوعة الطبية الفتهية، 712/5. 
الاختلاط يكون بالحجر الصحي للمرضى داخل الدولة، أو منع دخولهم أو خروجهم من البلاد الموبوءة.

وفرقت منظمة الصحة العالمية بين الحجر الصحي والعزل الصحي مــن فيــروس

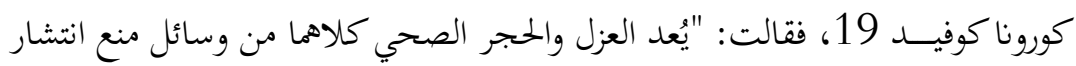

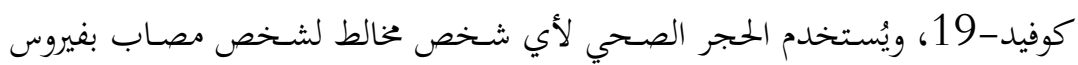

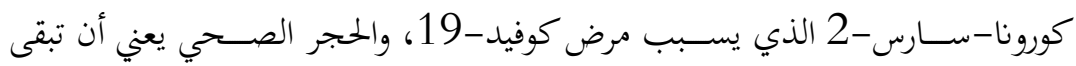

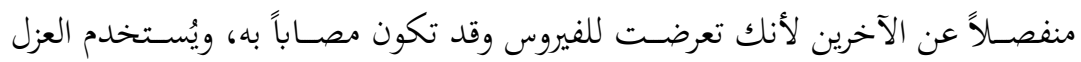

للأشخاص المصابين بأعراض كوفيد-19 أو الذين جاءت نتيجة اختبارهم إيجابية"(1). المطلب الثاني: نشأة الحجر الصحي. ألماضئ

أصلت الشريعة الإسلامية للحجر الصحي قبل أكثر من أربعة عشر قرنًا، فكان التحان

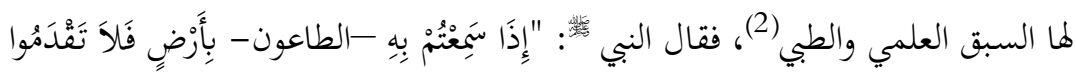

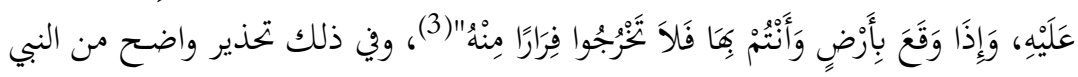

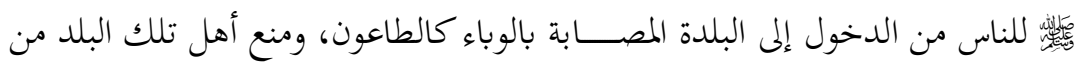

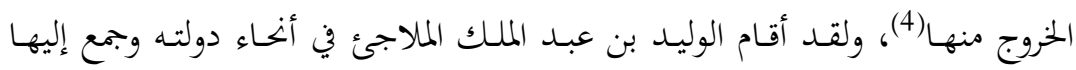
المجذومين وأجرى عليهم الأرزاق(5).

https://www.who.int/ar/news-room/q-a-detail/coronavirus- - 19 موقع منظمة الصحة العالمية disease-covid-19 (2) جدوع، حسين جبار، الإسلام أول من قنن الحجر الصحي في العالم، ضمن بحوث المؤتمر الدولي التاسع: (اتداعيات فيروس

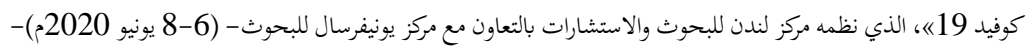

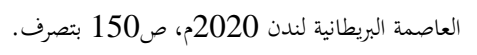

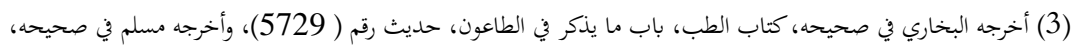

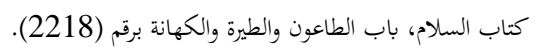

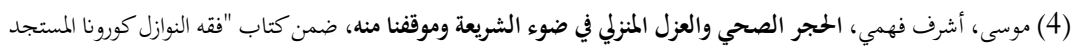

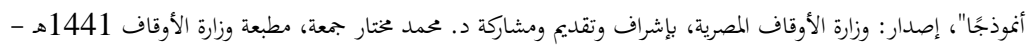

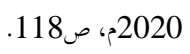

(5) ابن كثير، البداية والنهاية، تحقيق: علي الشيري، الناشر: دار إحياء التراث العرب، الطبعة: الأولى 1408هـ 1988م، 
وأما الحجر الصـحي بمعناه الاصـطلاحي المعاصـر، فقد كانت البندقية بإيطاليا

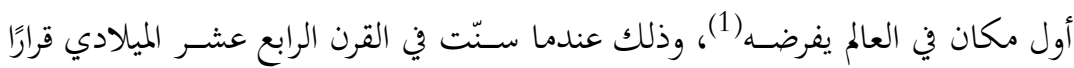
يقضـي بعدم السـماح للمسـافرين المشـتبه بإصـابتهم بمرض الطاعون من الدخول إليها،

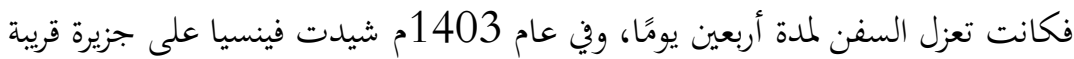

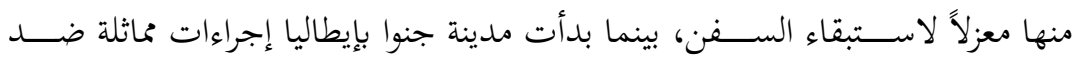
الطاعون في عام 1467م، ثم تبعتها بعد ذلك بلدان أخرى في أوروبا(2). ورغم هذا التقدم إلا أن الحجر الصحي لم يكن يطبق وفق بعل الأصول المحددة لمفهوم

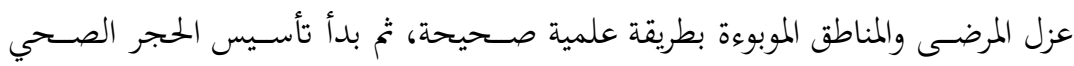

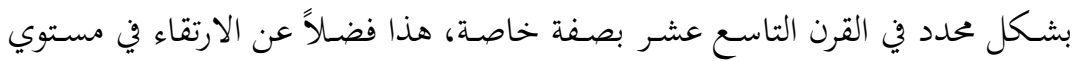

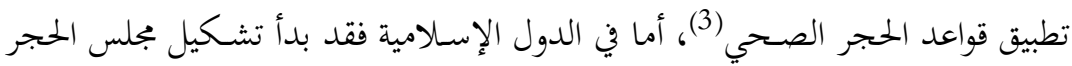

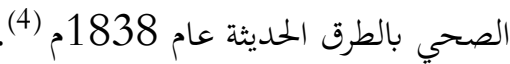

\section{المطلب الثالث: ضوابط الحجر الصحي في دولة الإمارات.}

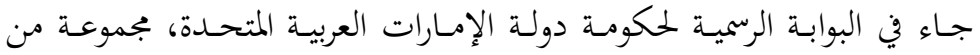
الإجراءات الخاصة بالحجر الصحي، ومنها:

(1) لقد رأيت كثيرا من الكتاب ينسبون لابن سينا أنه أول من توصل إلى طريقة العزل لمدة 40 يوماً، ولكني بجثت في مصدر هذا

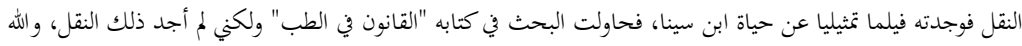

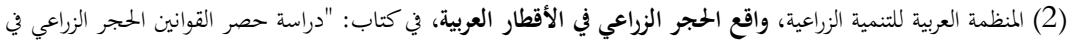

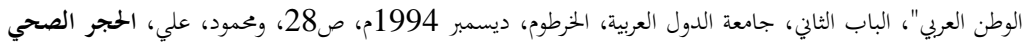

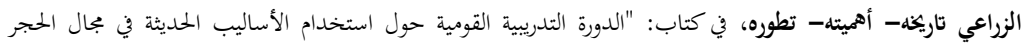

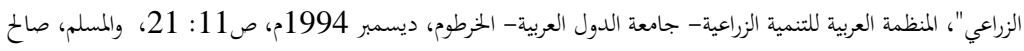

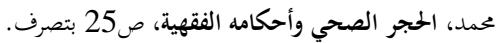

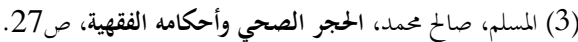

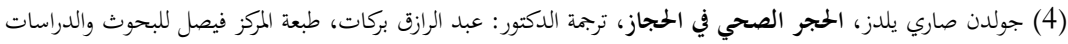

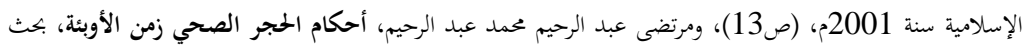

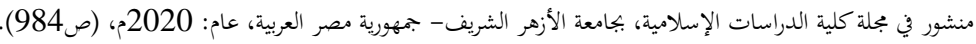




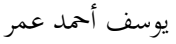

\section{أولاً: الحجر الصحي للمواطنين والمقيمين(1).}

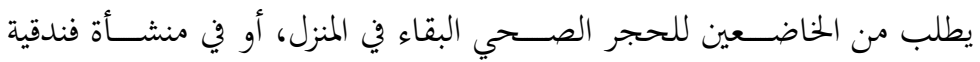

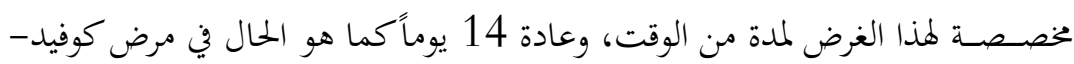

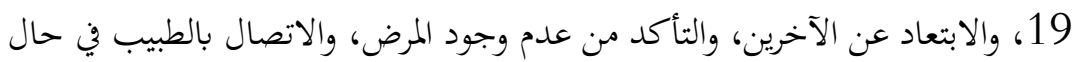

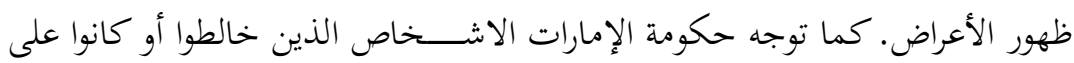

اتصـال بشـص مصـاب بكوفيد-19 بضـرورة تنفيذ تعليمات الحجر الصسحي، وتنزيل

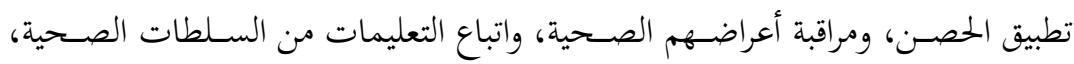
والاتصال بالطبيب إذا ظهرت عليهم الأعراض.

ثانياً: الحجر الصحي للمسافرين(2).

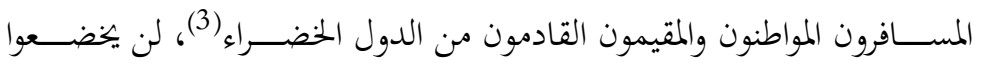

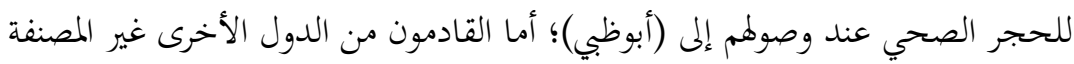

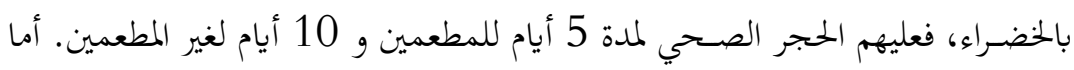

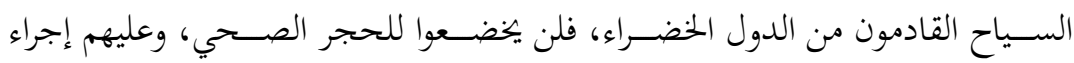
فحص كوفيد-19 (بي سـي آر) عند الوصـول، والعزل في المنزل أو الفندق لغاية ظهور

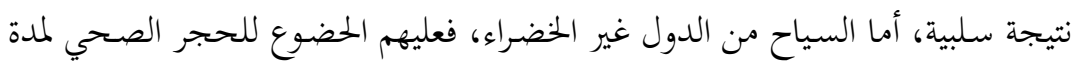
10

https://u.ae/ar-AE/information-and-services/justice- البوابة الرسمية لحكومة دولة الإمارات safety-and-the-law/handling-the-covid-19-outbreak/quarantining-to-fight-

covid-19 (2) البوابة الرسمية لحكومة دولة الإمارات: https:/u.ae/ar-ae/information-and-services/justice-safety-and-the-law/handlingthe-covid-19-outbreak/travelling-amid-covid-19/quarantine-guidelines-fortravellers-to-the-uae (3) الدول الخضراء هي الدول والمناطق والأقاليم المسموح بالسفر منها إلى (أبوظبي) مباشرة دون الحاجة لتطبيق إجراءات الحجر 


\section{ثالثاً: عقوبة مخالفة إجراءات الحجر الصحي(1).}

تعتبر مخالفة الشـخص إجراءات الحجر المنزلي، ومغادرة محل إقامته ومخالطته للغير

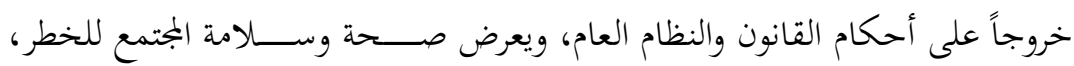
ويترتب على مخالفة تعليمات الحجر المنزلي أو الصحي غرامة قدرها

\section{المبحث الثاين: التأصيل الشرعي للحجر الصحي.}

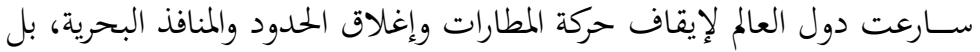

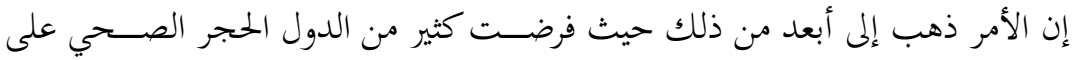
الناس في منازهم منعًا من فقدان السـيطرة على الوباء العالمي الذي يدعى بفيروس كورونا كوفيد 19)

فما الحكمة من الحجر الصـحي؟ وما مشـروعية الحجر الصـحي؟ وما الحكم التكليفي للحجر الصحي؟ هذا ما سنعرفه في المطالب الآتية.

\section{المطلب الأول: الحكمة من مشروعية الحجر الصحي.}

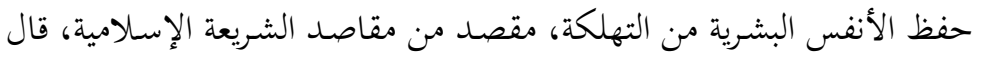

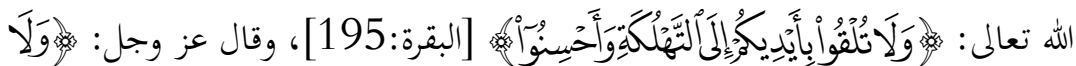

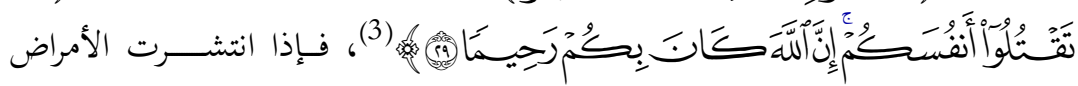

https://u.ae/ar-ae/information-and-services/justice- البوابة الرسمية لحكومة دولة الإمارات safety-and-the-law/handling-the-covid-19-outbreak/travelling-amid-covid19/quarantine-guidelines-for-travellers-to-the-uae

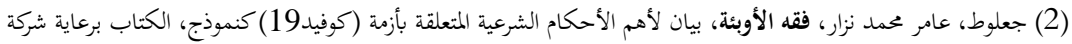

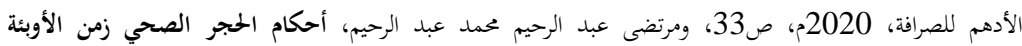




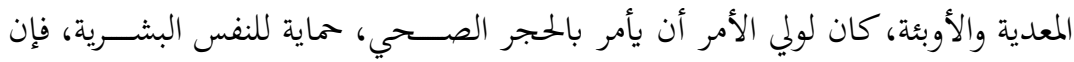

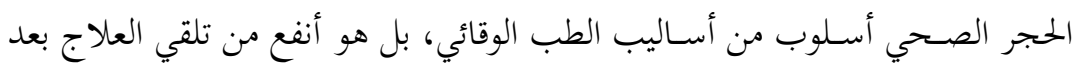

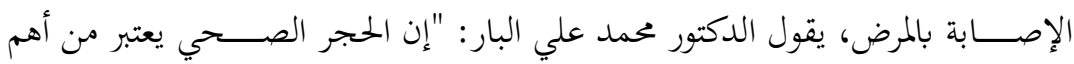
وسائل مقاومة انتشار الأمراض الوبائية"(1).

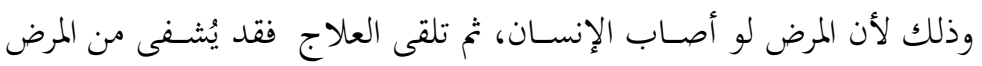

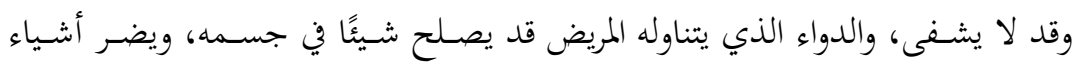

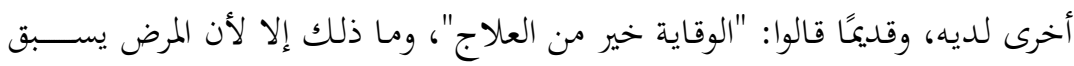

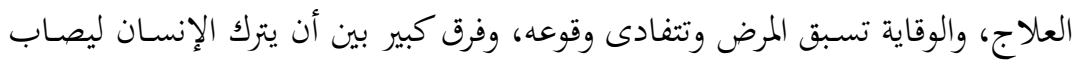

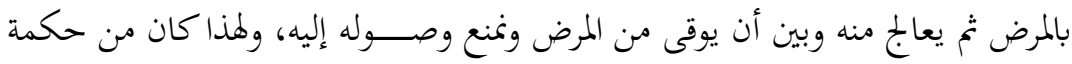

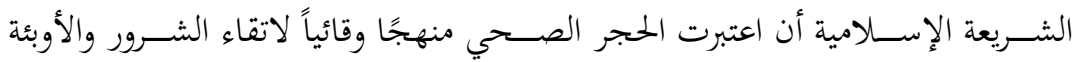
والأمراض قبل وقوعها وانتشــارها(2)، وكذلك اعتبرت الحجر الصــحي آلية لحفظ المال

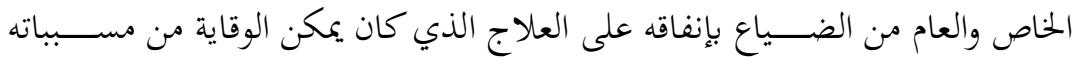
المرضية(3)

المطلب الثاني: مشروعية الحجر الصحي.

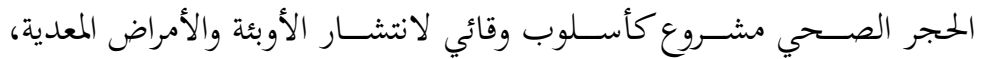

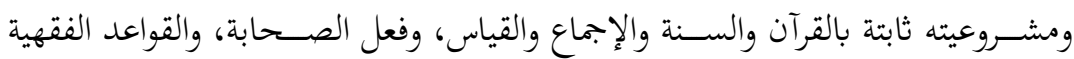
والأصولية والمقاصدية(4) (1) رضا، صالح أحمد، الإعجاز العلمي في السنة النبوية، مكتبة العبيكان-الرياض، الطبعة الأولى، سنة: 1421هـ-2001م،

(2) العقلا، غادة بنت محمد بن علي، الحجر الصحي بين الضرورة والآثار، بحث منشور في مجلة جامعة أم القرى لعلوم الشريعة

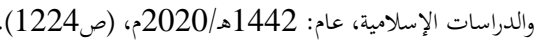

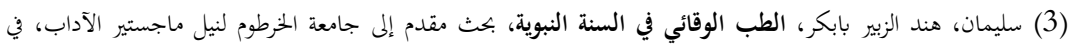

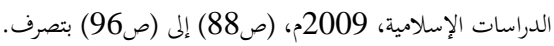

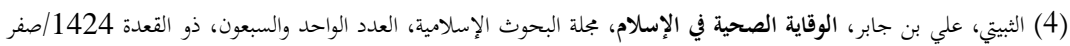

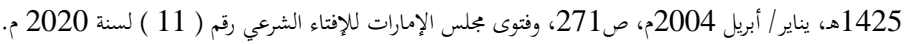


يمكننا أن نسـتدل على مشـروعية الحجر الصـحي بالآيات التي تدعو للحفاظ الحراظ

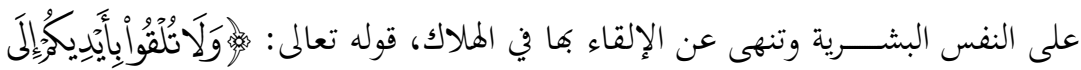

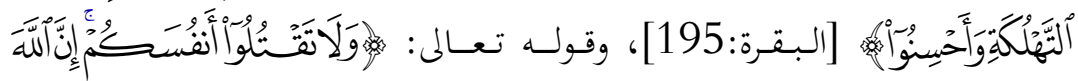

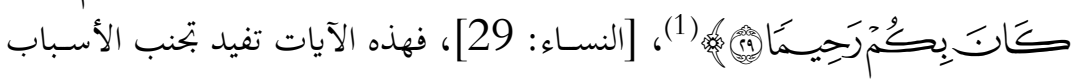

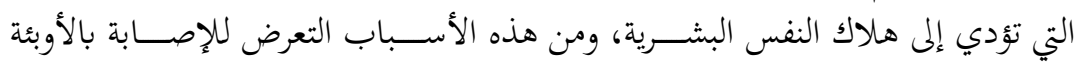

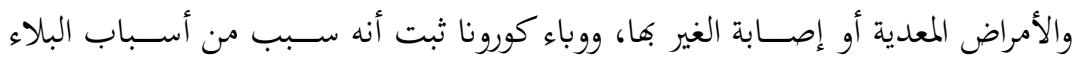

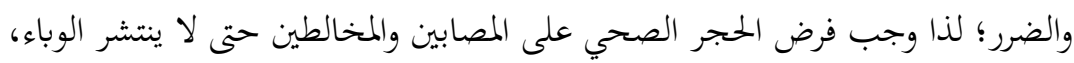

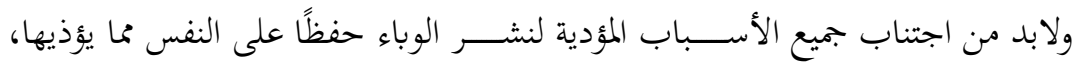

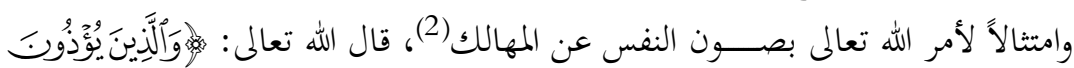

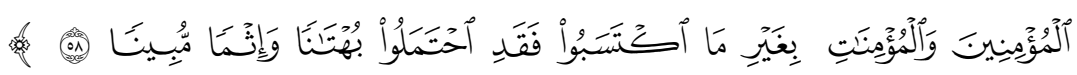
[الأحزاب:58].

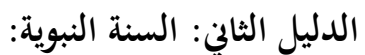

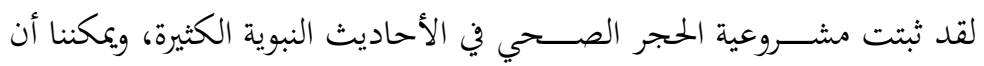

$$
\text { نقسم هذه الأحاديث إلى قسمين: }
$$

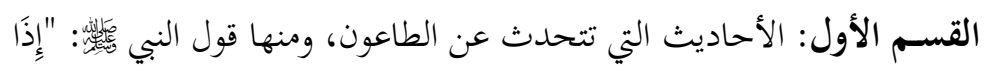

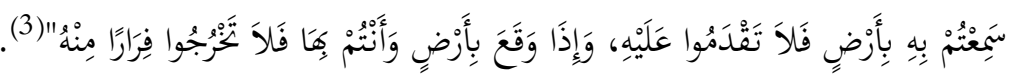

(1) سورة النساء: من الآية: [29].

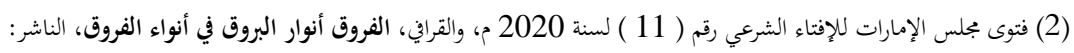

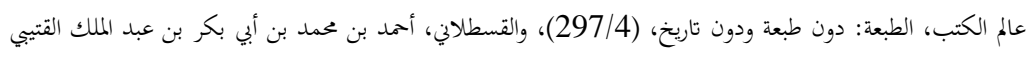

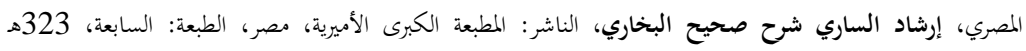

(3) أخرجه البخاري في صحيحه، كتاب الطب، باب ما يذكر في الطاعون، حديث رقم ( 5729)، وأخرجه مسلم في صحيحه،

كتاب السلام، باب الطاعون والطيرة والكهانة برقم (2218). 


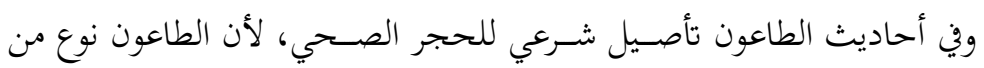

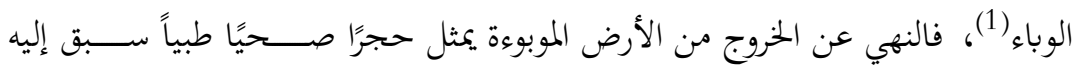

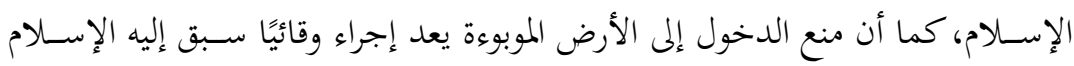

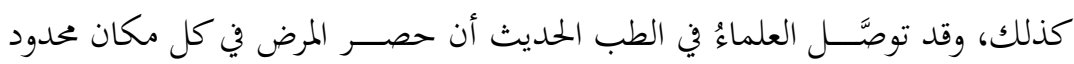
يتحقق بإذن الله بمنع الخروج من الأرض الموبوءة(2).

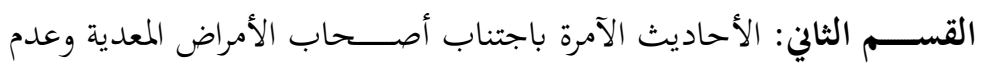

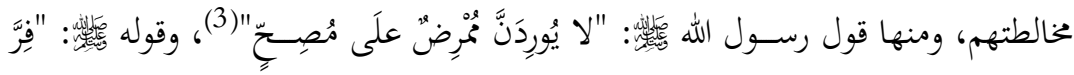

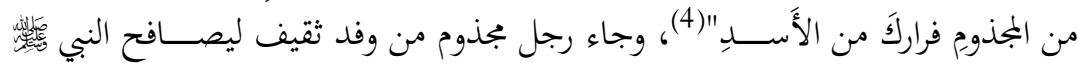

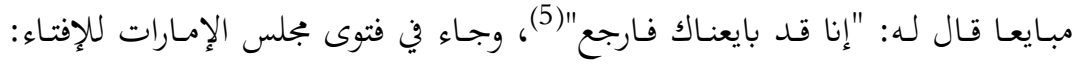

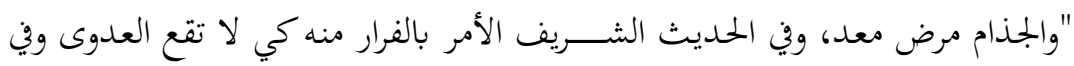
ذلك دلالة على إثبات التأثير للعدوى بإذن الله تعالى والحث على البحام البعد عن أسبابها"(6).

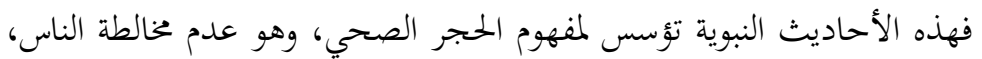
والابتعاد عن التجمعات واللقاءات، مخافة أن ينتشر المرض (7).

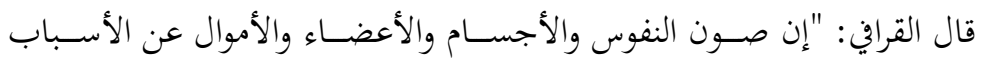

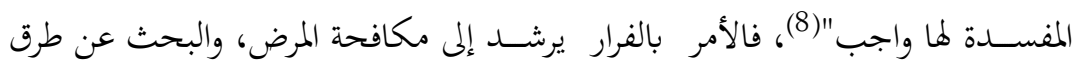

(1) الجوهري، إنماعيل بن حماد، الصحاح، تحقيق: أحمد عبد الغفور عطار ط:2158 دار العلم للملايين، بيروت 1399ه،

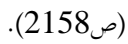

(2) الثبيتي، علي بن جابر، الوقاية الصحية في الإسلام، (صنام: (271).

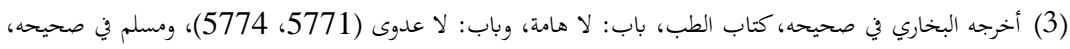

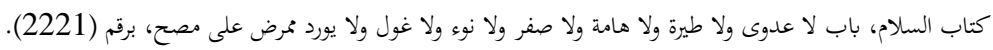

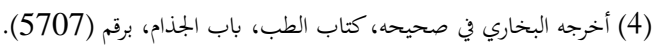

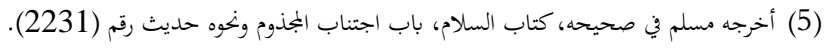

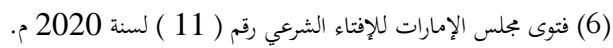

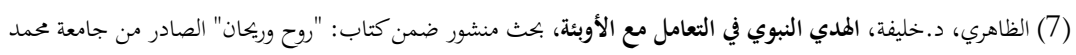




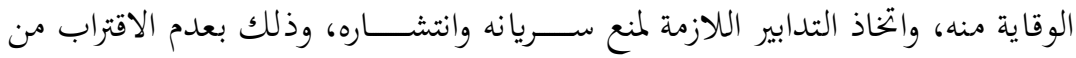

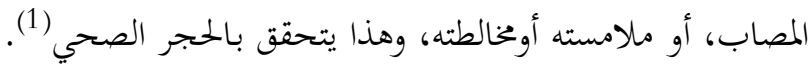

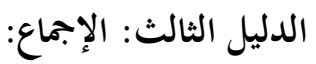
إن مما أجمع عليه العلماء عدم جواز الضرر، ووجوب إزالته، وإن مخالطة المصابين

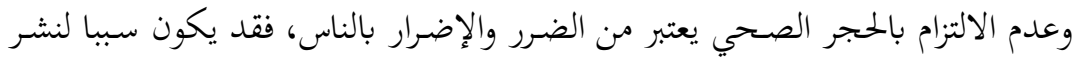
الوباء، ولقد جاء في فتوى مجلس الإمارات للإفتتاء ما نصـــهـ: "أجمع العلماء على ألى أنَّ:

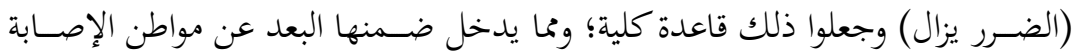

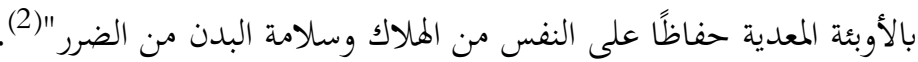
الدليل الرابع: القياس:

كل ما يؤذي الناس يجب كفه عنهم، فمن كان مصاباً بمرض من الأمراض المعدية

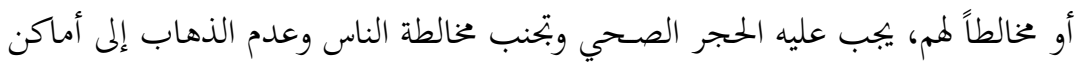

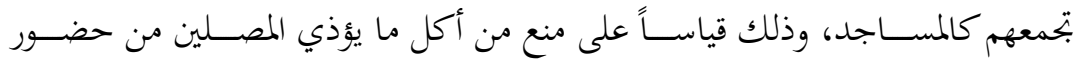

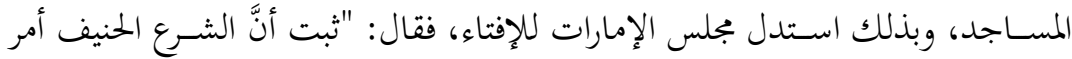

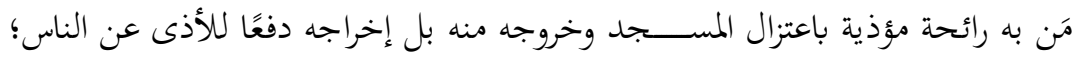

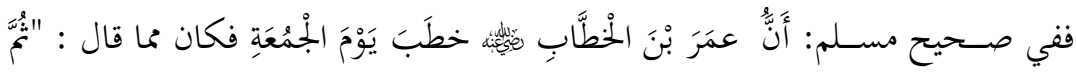

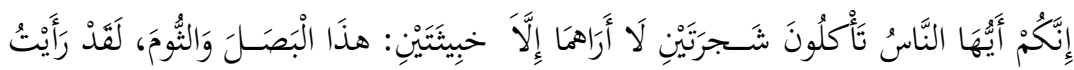

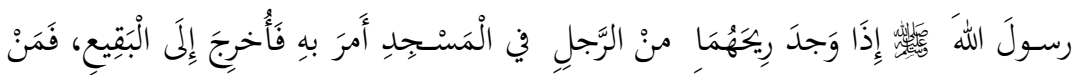

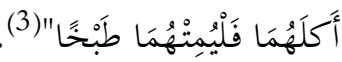

فإذا كان هذا الإخراج لمجرد الأذية بالرائحة الكريهة؛ فكيف بأذية العدوى التي

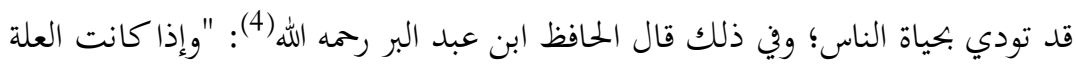
(1) الجندي، أسامة فخري، تقييد المباح، من كتاب: "فقه النوازل كورونا المستجد أنموذجًا"، إصدار: وزارة الأوقاف المصرية،

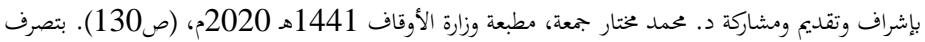

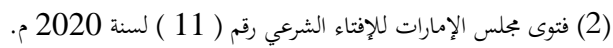

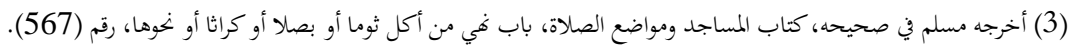

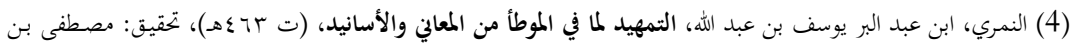

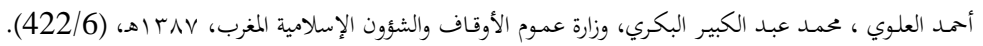




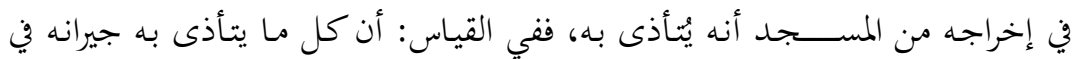

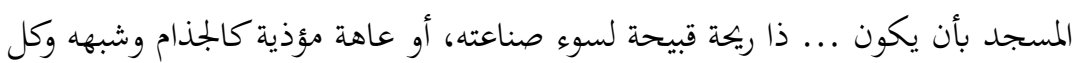

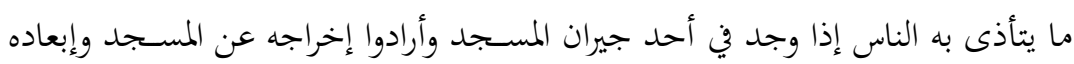

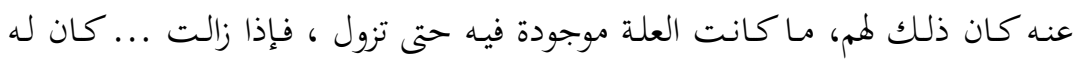

مراجعة المسجد"(1).

\section{الدليل الخامس: فعل الصحابة:}

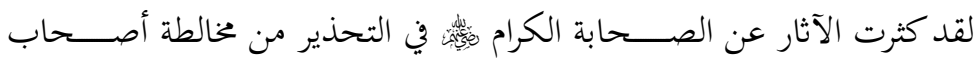

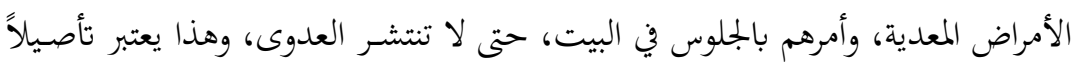
للحجر الصحي، ومن هذه الآثار:

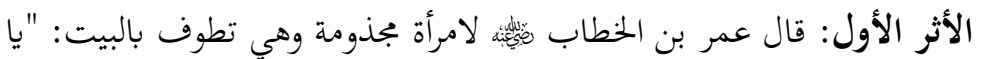
أمة الله لا تؤذي الناس لو جلســت في بيتك"(2)، قال ابن عبد البر -رحمه الله-: "يحال

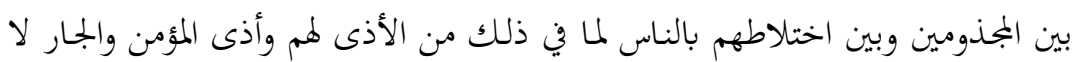
يحل "(3)

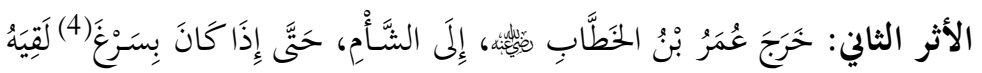

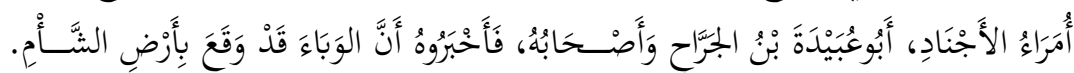

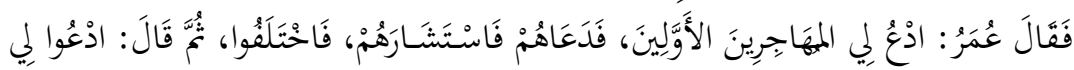

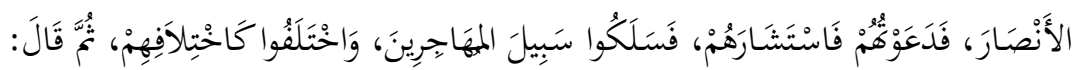

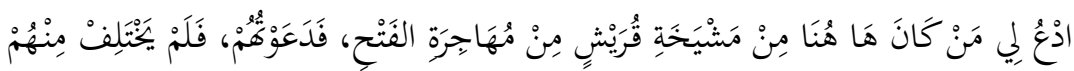

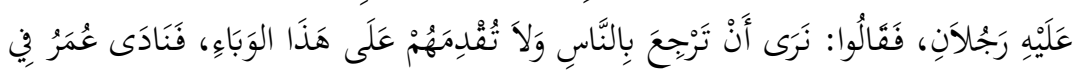

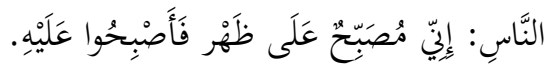

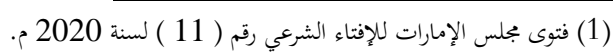

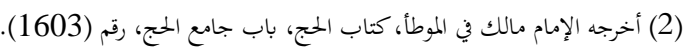

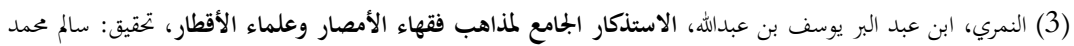

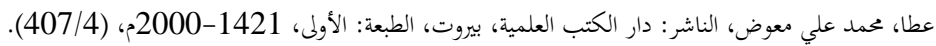

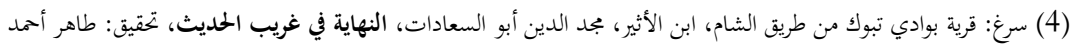

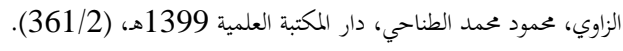


وهذا الأثر يعد تطبيقًا عمليًا للحجر الصـحي، وذلك برأي أفاضـل الصـحابة

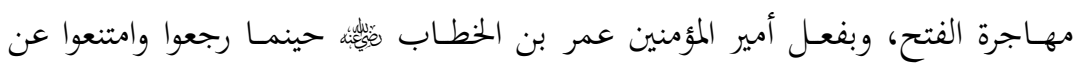
دخول الأرض الموبوءة(1).

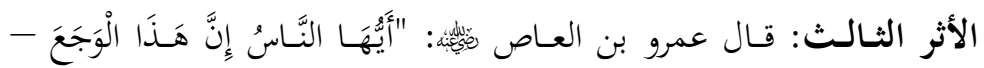

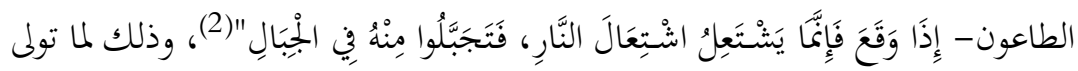

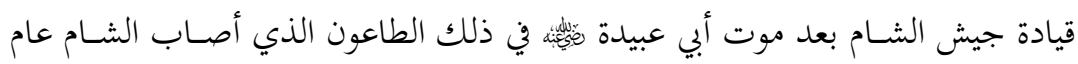
18ه، المعروف بطاعون عمواس، وفي هذا الأثر عدم مخالطة الناس. الدليل السادس: القواعد الفقهية والأصولية والمقاصدية:

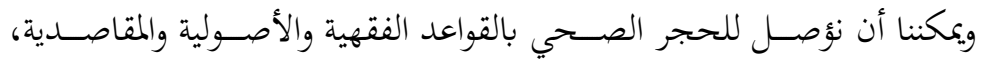

القاعدة الأولى: "لا ضرر ولا ضرار"(3)، ونص هذه القاعدة لفظ لحديث النبي

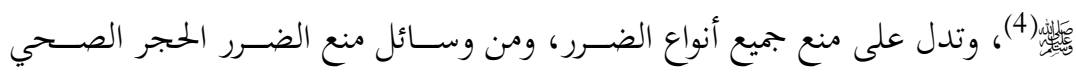

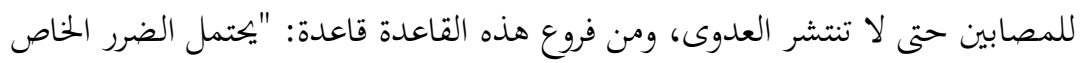

(1) أخرجه البخاري في صحيحه، كتاب الطب، باب ما يذكر في الطاعون، حديث رقم ( 5729)، وأخرجه مسلم في صحيحه،

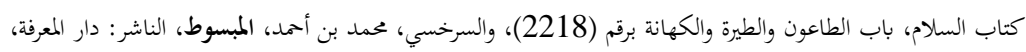

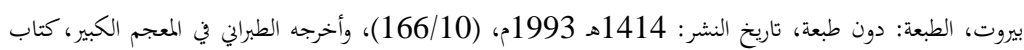

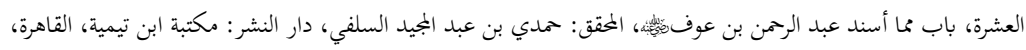

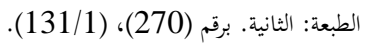

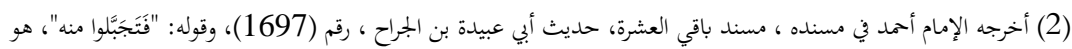

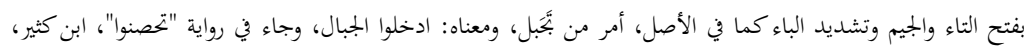

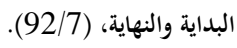

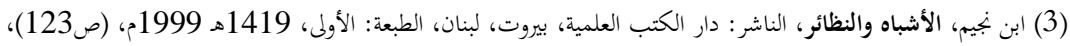

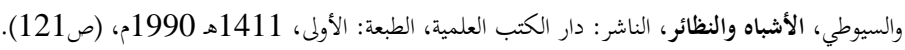

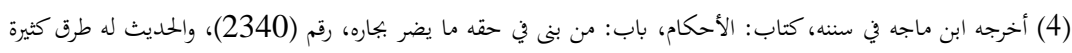

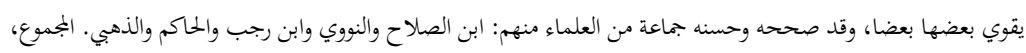

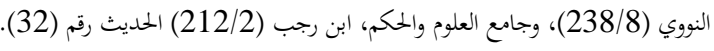


لدفع الضـرر العام"(1)، فالحجر الصـحي وإن كان به بعض الضـرر على المحجور بتقييد حريته، إلا أن هذا يعد ضررًا خاصًا يتحمل من أجل دفع الضرر العام وهو انتشار الوباء

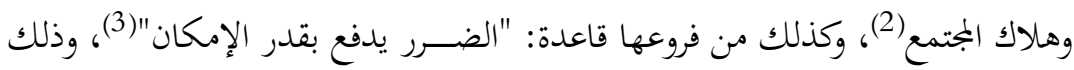
بدفع الضـرر قبل وقوعه بكل وسيلة من الوسائل، فالوقاية خير من العلاج، فإن لم يمكن دفعه بالكلية، فبقدر ما يمكن (4).

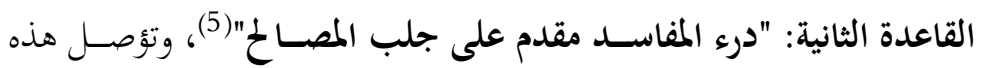

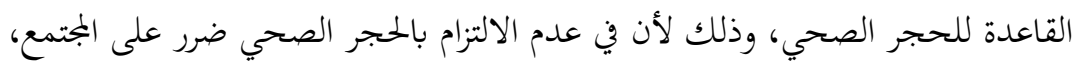

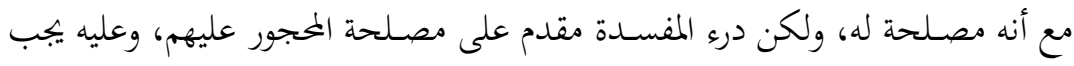

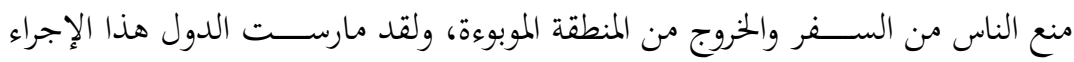

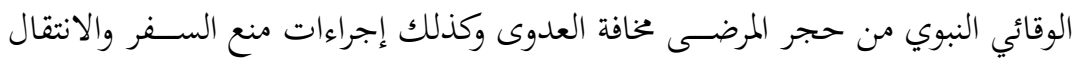
من بلد لبلد حتى تتمكن الدول من تطويق المرض والحدد من العدوى المعائ.

(1) ابن نجيم، الأشباه والنظائر (ص87)، الزرقا، أحمد، شرح القواعد الفقهية، دار القلم، سنة النشر: 1409، 1989م،

المبرد، إيمان عبد العزيز، الثدابير الوقائية من الأمراض والكوارث، رسالة مقدمة لنيل درجة الماجستير في الفقه، بكلية

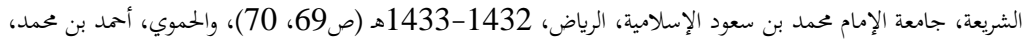

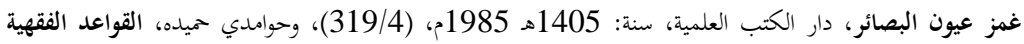

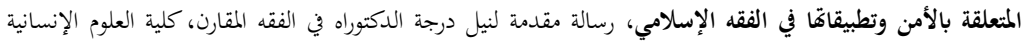

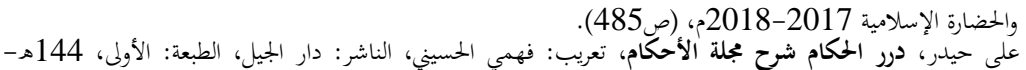

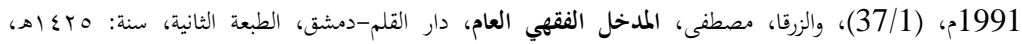

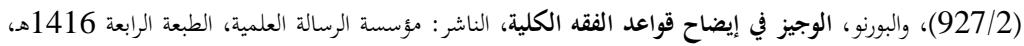

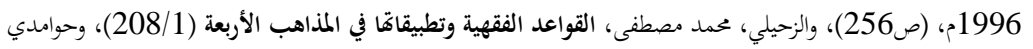

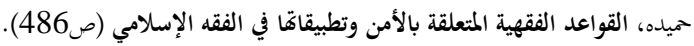

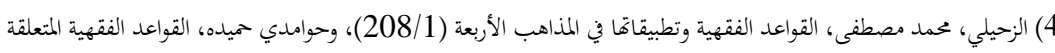

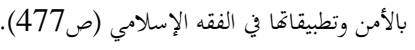

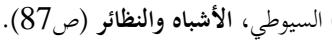

(6) بكراوي، محمد عبد الحق، الثكاليف الشرعية في زمن كورونا بين الرخصة والعزيمة، المؤتمر الدولي التاسع الذي نظمه مركز

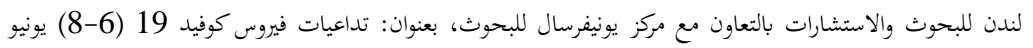

$$
\text { 2020م، (صن66) }
$$


القاعدة الثالثة: "الضــــرورات تبيح المخظورات"، لإِنســـان حق حرية التنقل

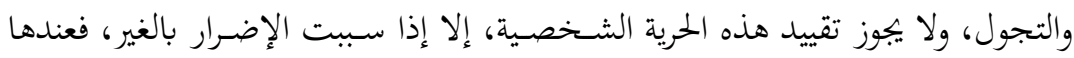

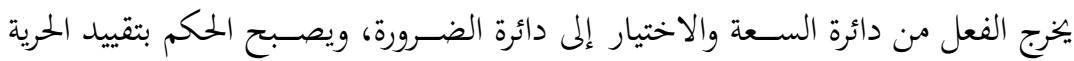

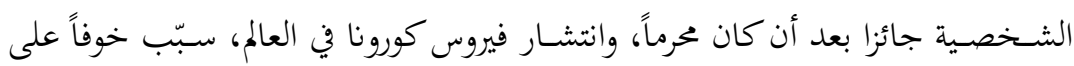

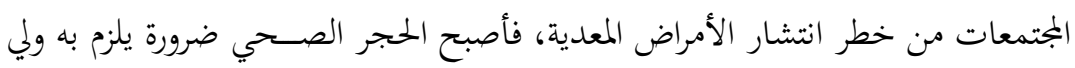

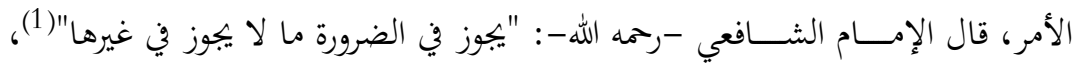

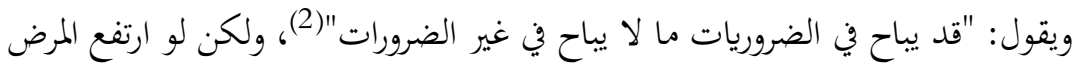

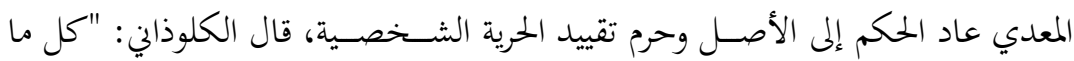
أبيح للضرورة وزالت الضرورة لم يجز فعله" (3).

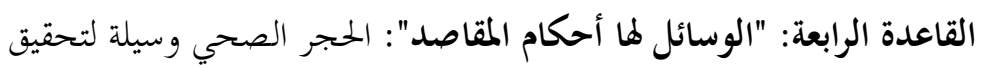

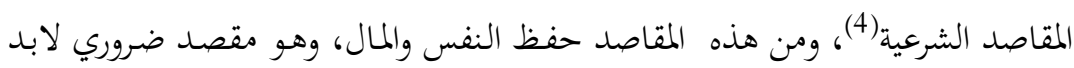

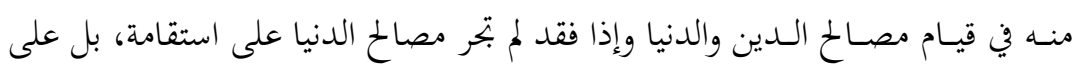
فساد وتمارج وفوت حياة وخسران مبين(5). وإذا كـان مقصـد حفـظ النفس والمـال مـن المقاصــ الضـرورية كـان الامتثـال

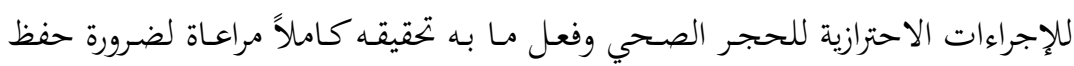

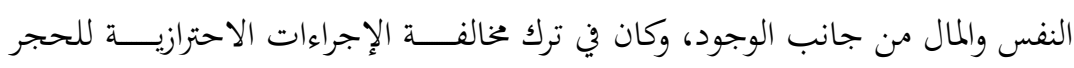

$$
\text { (2) الشافعي K الأم (142/4) (148/4). }
$$

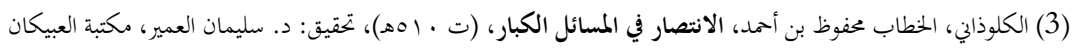

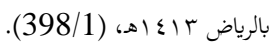

(4) علم مقاصد الشريعة هو عبارة عن الوقوف على المعاني والحكم الملحوظة للشارع في جميع أحوال التشريع أو معظمِها. ابن

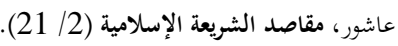

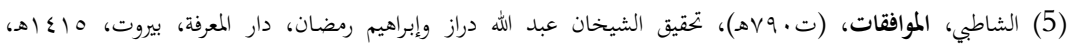

$$
\text { (324/2)، بتصرف يسير. }
$$


الصحي مراعاة لضرورة حفظ النفس والمال من جانب العـدم، ومـا ذلك إلا لأن الحجر

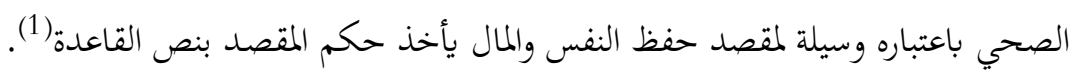

\section{المطلب الثالث: الحكم التكليفي(2) للحجر الصحي.}

يجب الحجر الصسحي إذاكان المرض معديا كفيروس كورونا - كوفيد 19، لأنه

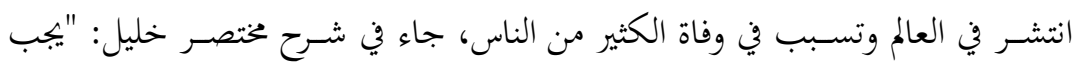

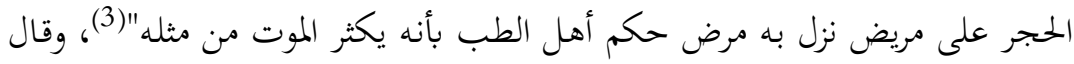

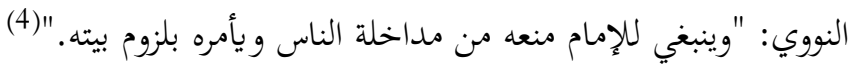

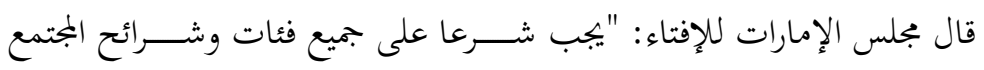

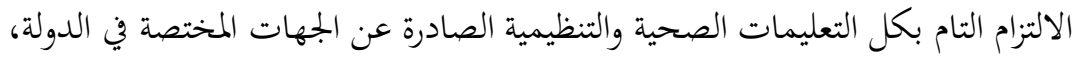

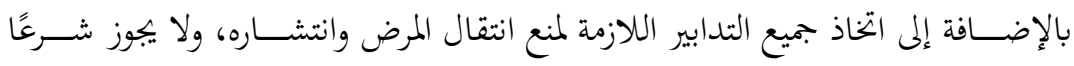
مخالفتها بأي حالٍ من الأحوال.

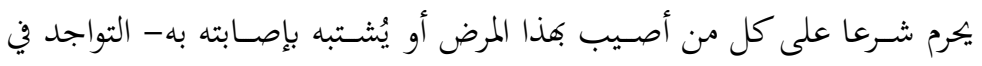

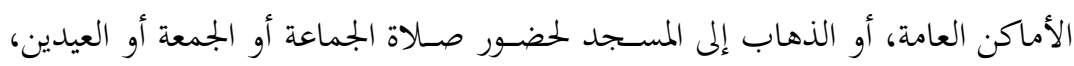

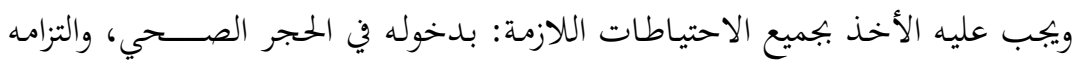

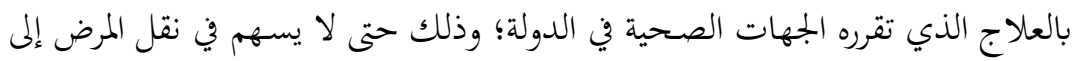

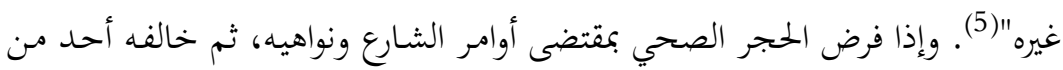

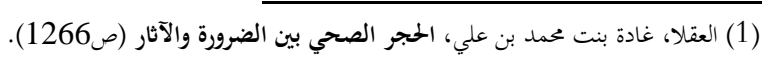

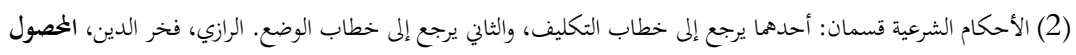

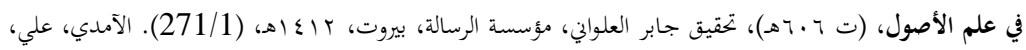

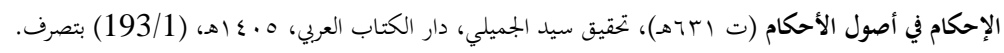

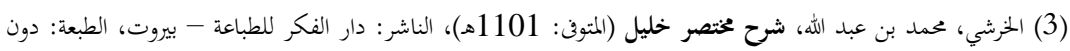

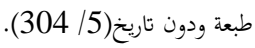
(4) النووي، حيي الدين يجيى بن شرف، المنهاج شرح صحيح مسلم بن الحجاج، (المتوف: 676هـ)، الناشر: : دار إحياء التراث

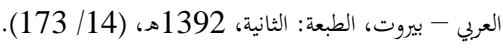

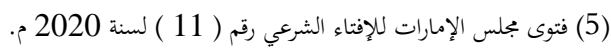


الأفراد المخاطبين بحكمه التكليفي فإنه يعد آثنًا ومستهينًا بأوامر الشارع ونواهيه، ولكن

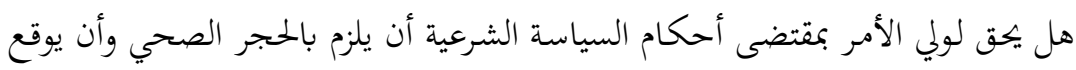
العقوبة على المخالف؟ هذا ما سنعرفه في المبحث الآتي:

المبحث الثالث: التأصيل الثرعي لسلطة ولي الأمر في الإلزام بالحجر الصحي.

\section{المطلب الأول: مشروعية إلزام ولي الأمر بالحجر الصحي.}

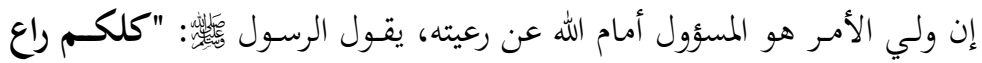

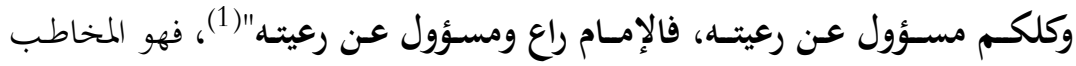

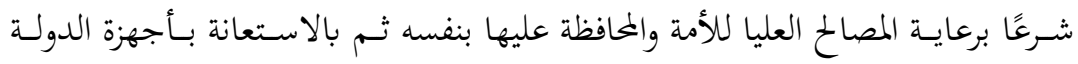

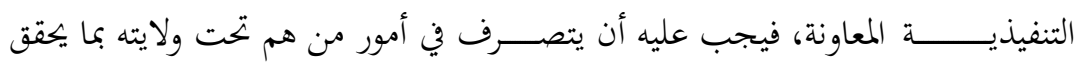

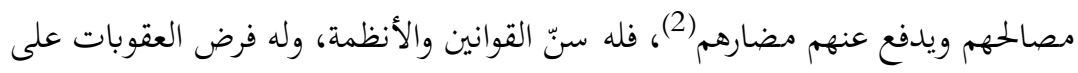
من يخالف النظام، ويتعالى على القانون، ولا يبالي بحقوق الآخرين (3).

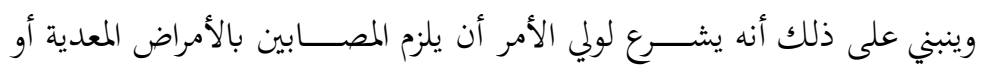

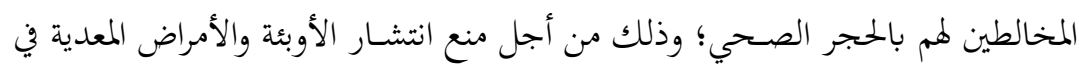

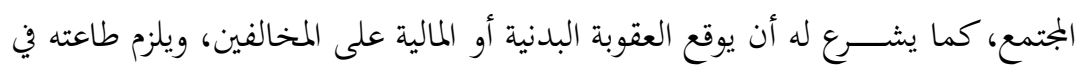
ذلك حفاظًا على الصحة العامة (4).

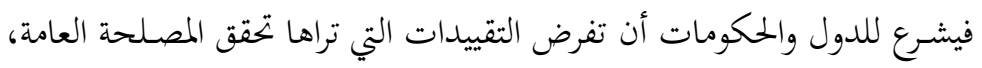

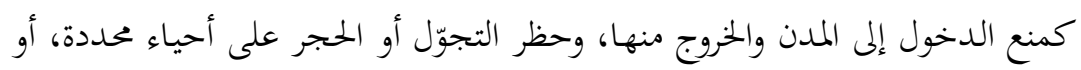

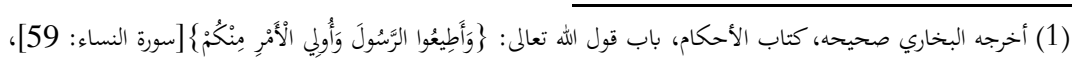

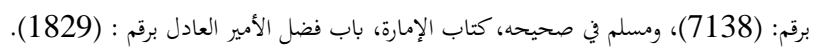

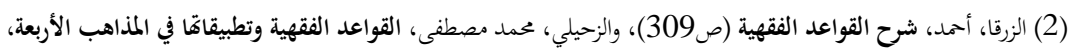

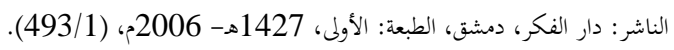

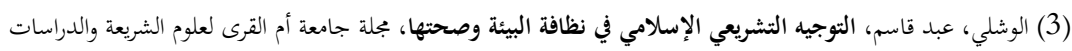

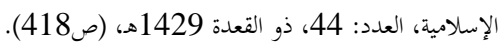

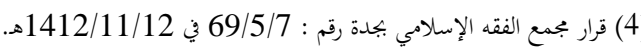


المنع من الســفر، أو المنع من التعامل بالنقود الورقية والمعدنية وفرض الإجراءات اللازمة

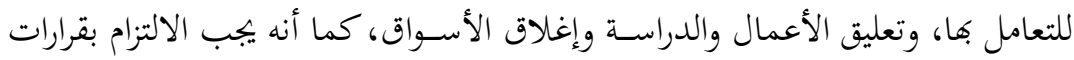

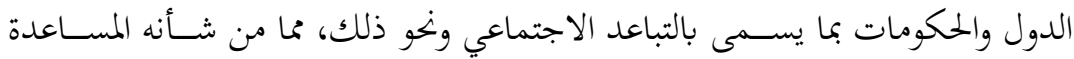

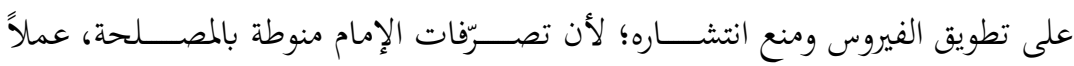

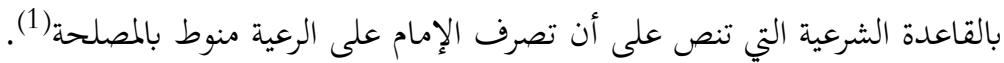

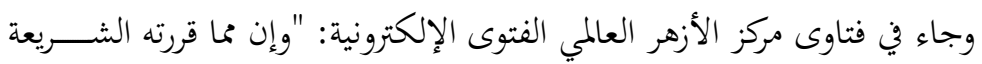

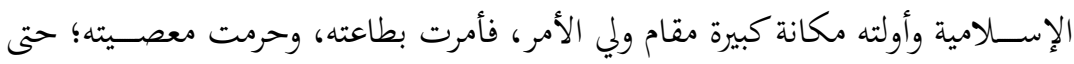

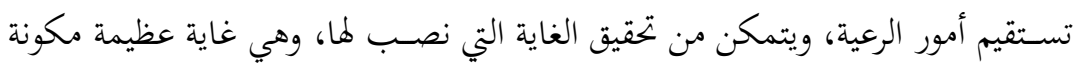
من أصلين: الأول: نصرة الدين، والحفاظ على أصوله وقواعده.

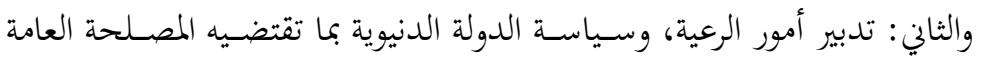
المعتبرة.

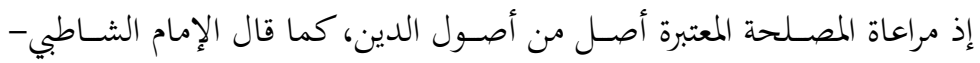
رحمه الله-: "استقرينا من الشريعة أها وضعت لمصالح العباد"(2).

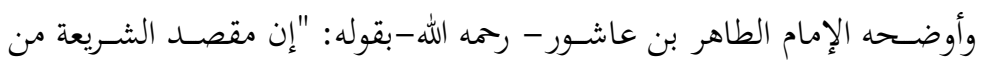

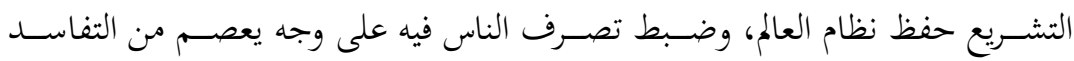

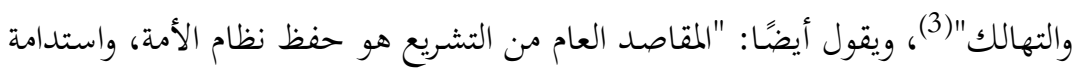

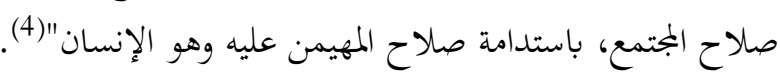
(1) توصيات الندوة الطبية الفقهية الثانية لهذا العام بعنوان: "فيروس كورونا المستجد (كوفيد-19) وما يتعلق به من معالجات طبية

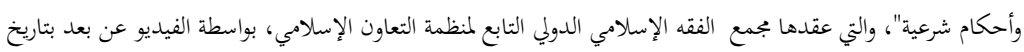

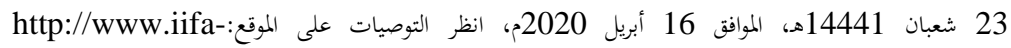
aifi.org/5254.html (2) الشاطبي، الموافقات (12/2). (3) ابن عاشور، محمد الطاهر، مقاصد الشريعة الإسلامية، الخقق: محمد الحبيب ابن الخوجة، الناشر: وزارة الأوقاف والشؤون

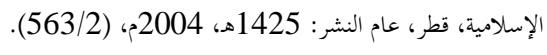


ولذلك فقـد كفلت الشــريعة الإســـلامية لولي الأمر تـبير كثير من الأمور

الاجتهادية وفق اجتهاده الذي يتوصــلـل إليه بعد النظر الســليم، والبحث والتحري،

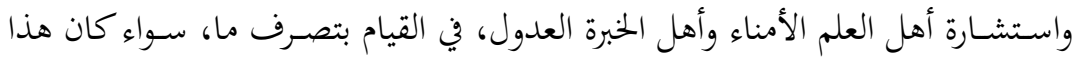

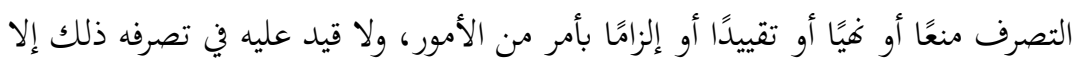

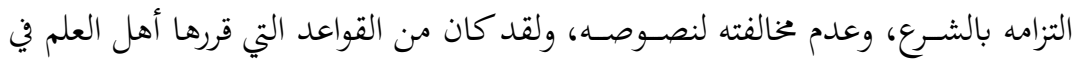

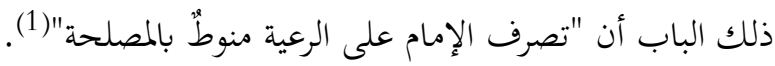

\section{المطلب الثاني: التأصيل الشرعي لإلزام ولي الأمر بالحجر الصحي.}

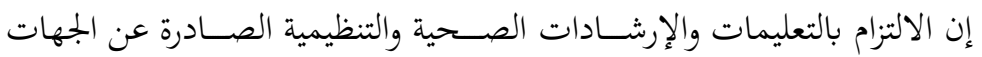

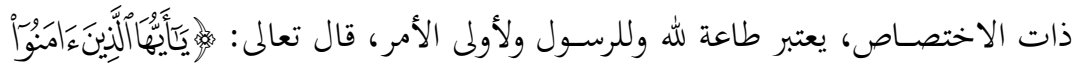

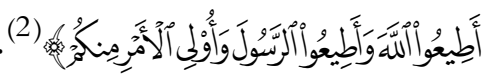
وأكد ذلك رســـول الله بقوله: "من أطاع الأمير فقد أطاعني، ومن عصى الأمير فقد عصاني، ومن عصاني فقد عصى الله"(3).

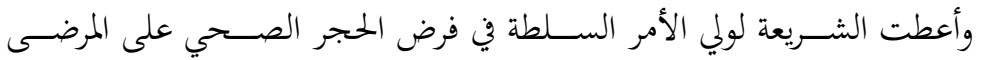

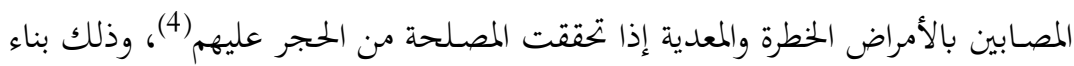

(1) الديليل الشرعي للتعامل مع فيروس كورونا المستجد كوفيد 19، الصادر عن مركز الأزهر العلمي للفتوى الإلكتروني، الطبعة الأولى 2020م. الموقع على الشبكة العنكبوتية:

http://www.azhar.eg/fatwacenter/fatwa/qadaya/ArtMID/7988/ArticleId/50148

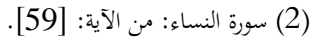

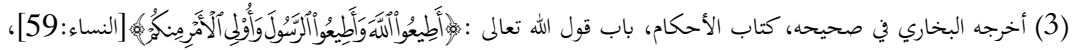

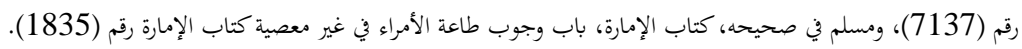

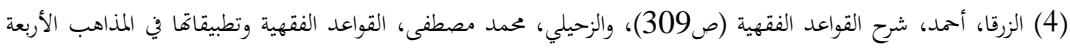


على قاعدة: "لولي الأمر تقييد المباح"(1)، وقاعدة: "تصـــف الإمام على الرعية منوط بالمصلحة" (2)، ويلزم طاعته في ذلك حفاظًا على الصحة العامة(3).

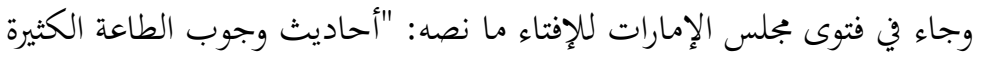

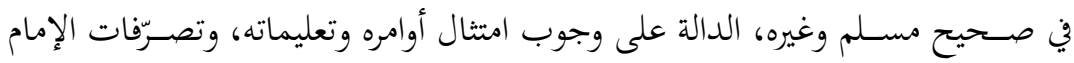

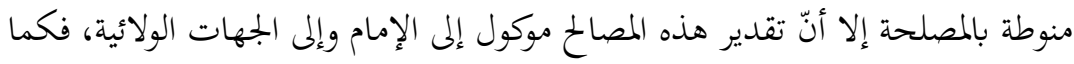

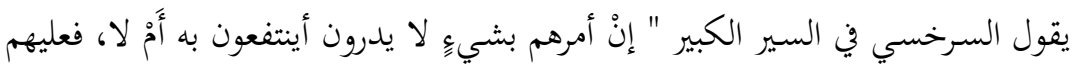

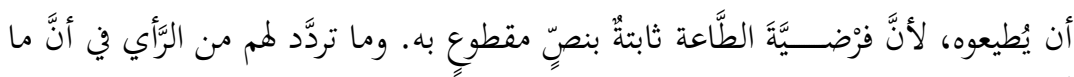

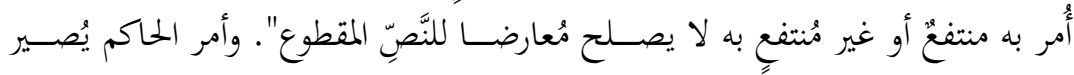

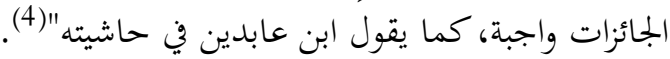

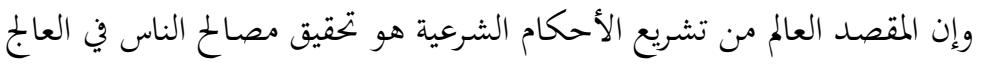

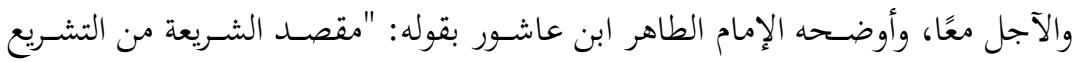

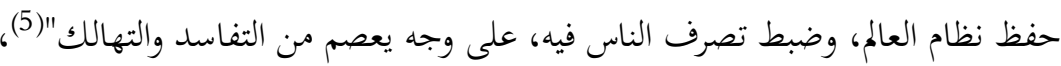

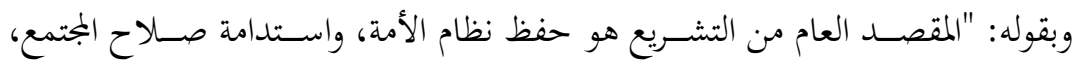

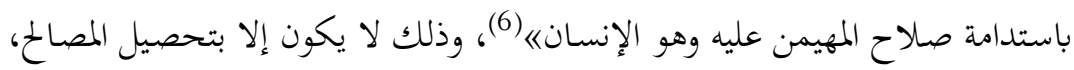
واجتناب المفاسد(7).

(1) وهو قول الجمهور خلافاً للظاهرية وبعض الشافعية. ابن عابدين، حاشية رد المختار (حاشية ابن عابدين)، دار الفكر-

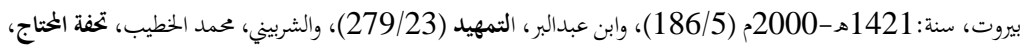

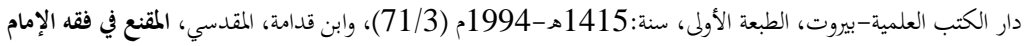

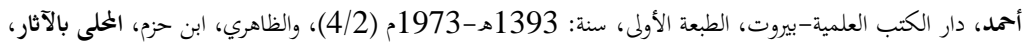
دار الفكر-بيروت (364/9). (2) ابن نجيم، الأشباه والنظائر (صرات (363) (123)، والسيوطي، الأشباه والنظائر (ص121).

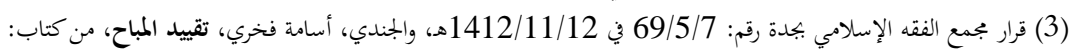

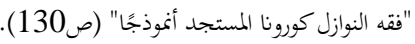

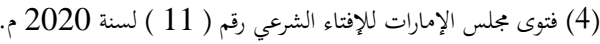

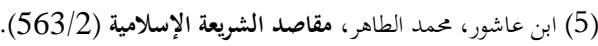

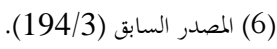
(7) موقع اليوم السابع: هيئة كبار العلماء بمصر تصدر بيانا الثاني حول كورونا، الجمعة، 3 أبريل، 2020م، الموقع على الشبكة /https://www.youm7.com العنكبوتية: 
وفي وضـوء مقاصـد الشـريعة وقواعدها، التي منها: "لا ضـرر ولا ضـرار"(1)، فإن

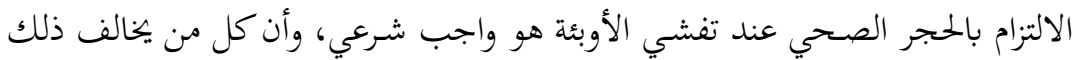

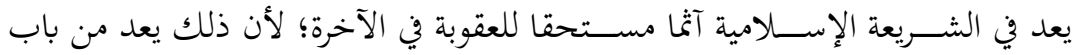

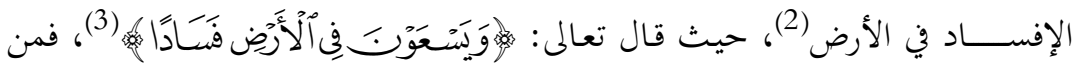

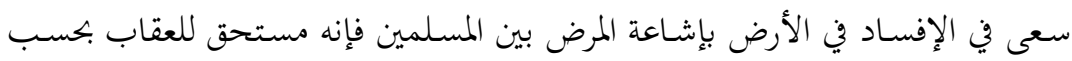
المرض الذي سعى في نقله بين الناس، وخطورته، وأثره.

\section{المطلب الثالث: التأصيل الشرعي لعقاب المخالفين للحجر الصحي.}

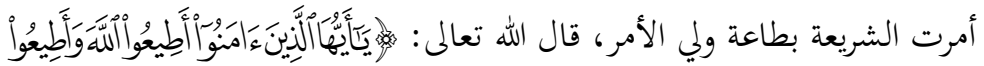

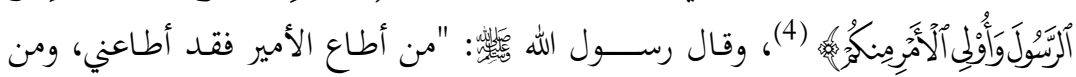

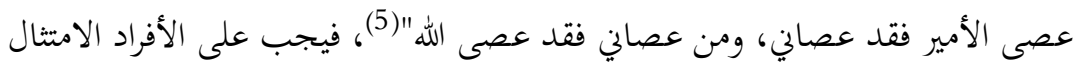

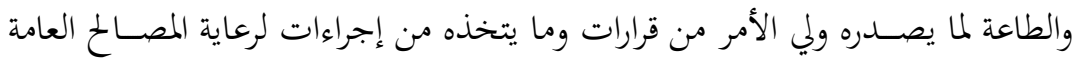
والمحافظة عليها.

وفي الجانب الآخر أوجبت الشريعة على ولي الأمر مسؤولية المحافظة على المصالح

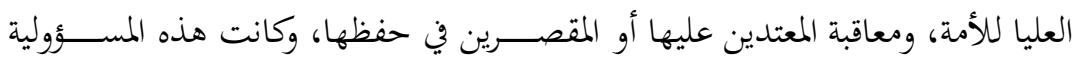

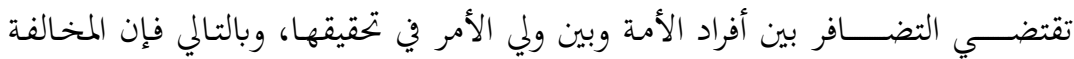

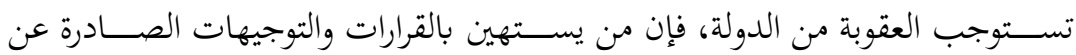

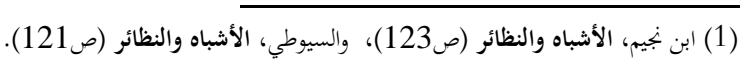

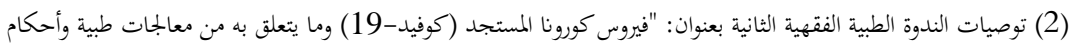

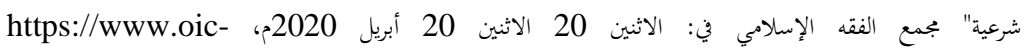
oci.org/topic/?t_id=23343\&t_ref=13985\&lan=ar

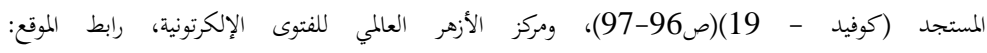
https://cutt.us/WwsMZ

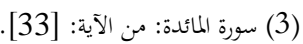

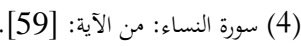

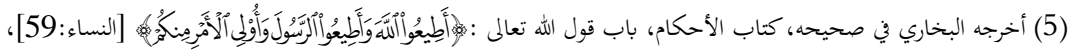
رقم (7137)، ومسلم في صحيحه، كتاب الإمارة، باب وجوب طاعة الأبحاب نأمراء في غير معصية كتاب الإمارة رقم (1835). 
الجهات المختصــة المســؤولة عن مكافحة تفشـي فيروس كورونا المســتجد، يعدّ مخالفاً

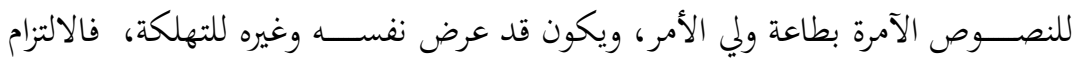

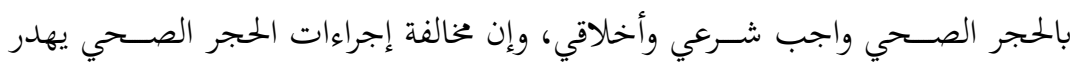

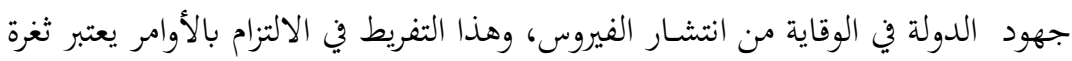
ينفذ منها هذا المرض وتضييع كثير من الجهود وتسبب مشاكل كثيرة لا تحمد عقباها.

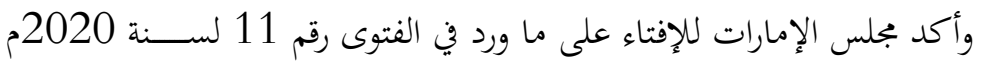

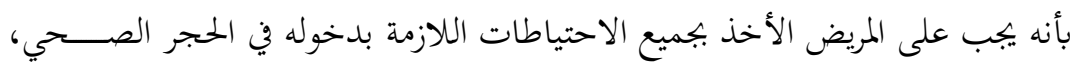

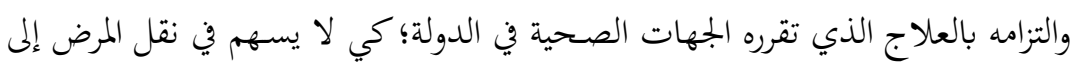
غيره، ومن فعل خلاف ذلك فهو آتمُ شرعاً ومعاقبُ قانوناً(1).

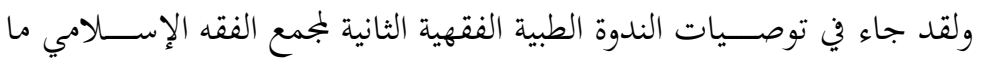
نصـــه: "لا يجوز لمن ظهرت عليه أعراض المرض أن يخفي ذلك عن الســـلطيات الطبية

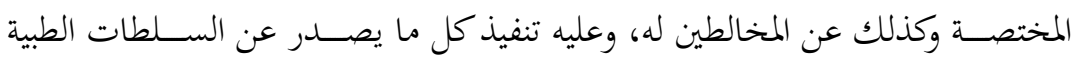
المختصة، ولما أن تعزر من أصيب بهذا المرض وأخفاه"(2).

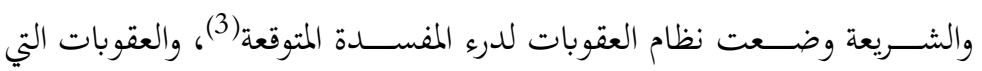

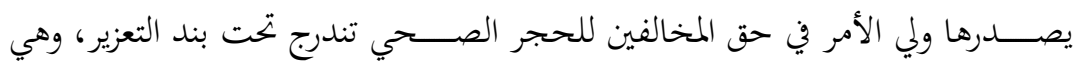

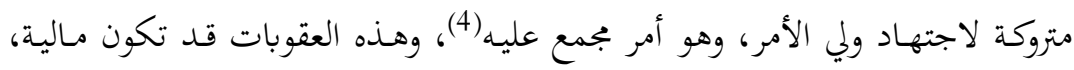

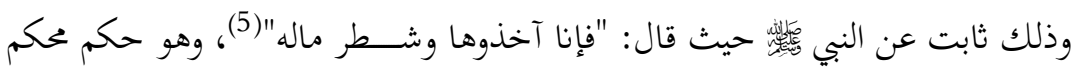

(1) مقال في بيان: (الإمارات للإقتاء الشرعي): القاح كورونانها لا يفسد الصيام، الحميس 8 ابريل 00:52 جريدة الاتحاد. https://www.alittihad.ae/new

(2) توصيات الندوة الطبية الفقهية الثانية بعنوان: "فيروس كورونا المستجد (كوفيد-19) وما يتعلق به من معالجات طبية وأحكام

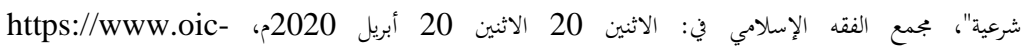
.oci.org/topic/?t_id=23343\&t_ref=13985\&lan=ar

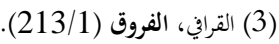

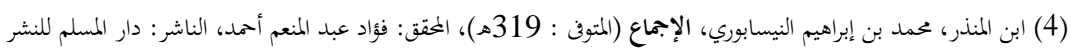

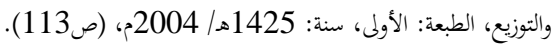

(5) أخرجه أبوداود في سنه، كتاب الزكاة، باب في زكاة السائمة، رقم (14575) (1575). 
غير منسوخ، وعليه فإن ما جاء من عقوبة مخالفة إجراءات الحجر الصحي، وأنه "يترتب

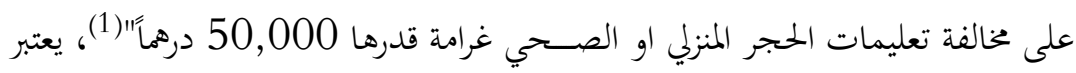
عقوبة مشروعة شرعاً وهي من سلطة ولي الأمر للحفاظ على النفس البشرية.

الخاتمة

ويف الختام لا يسـعنا إلا أن ندعو الله أن يرفع هذا البلاء ويشـفي المصـابين بهذا الداء، وسأذكر بعض النتائج التوصيات:

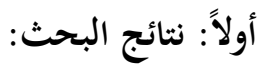
1- الحجر الصحي مؤصل شرعيا في الفقه الإسلامي.

2- الحجر الصحي هو : منع الخروج من البلد الذي فيه الوباء أو الدخول فيه.

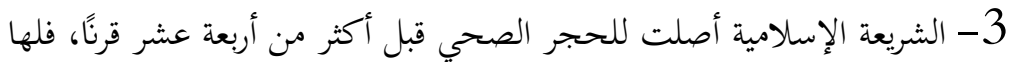

$$
\text { السبق العلمي والطبي. }
$$

4- الحجر الصحي أسلوب من أساليب الطب الوقائي، بل هو أنفع من تلقي

$$
\text { العلاج بعد الإصابة بالمرض. }
$$

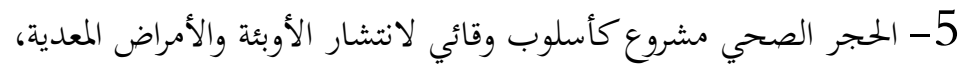

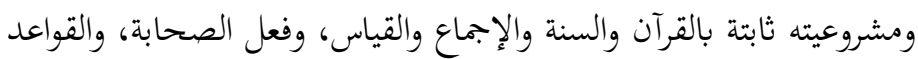

$$
\text { الفقهية والأصولية. }
$$

6- رسالة الإسلام عالمية تتناسب مع كل الأزمنة وسائر الأمكنة.

7- الحجر الصحي واجب يأثم من يخالفه إذا سبب انتشار الأمراض المعدية.

$$
\text { 8- تصرف الحاكم في أمور من هم تحت ولايته منوط بالمصلحة. }
$$

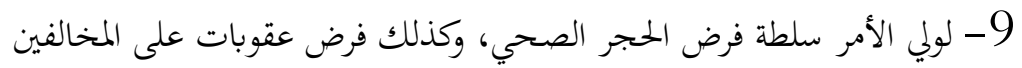

$$
\text { وذلك لرعاية المصالح العليا للأمة. }
$$

https://u.ae/ar-ae/information-and-services/justice- البوابة الرمية لحكومة دولة الإمارات: safety-and-the-law/handling-the-covid-19-outbreak/travelling-amid-covid19/quarantine-guidelines-for-travellers-to-the-uae 
10- يجب شرعًا على الجميع الالتزام الكامل بجميع التعليمات والإرشادات الصحية والتنظيمية الصادرة عن الجهات ذات الاختصاص، طاعة لله تعالى، ولأولي الأمر.

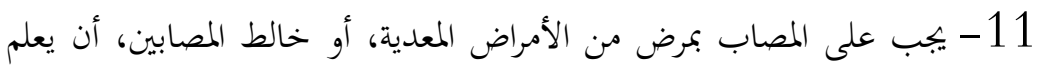

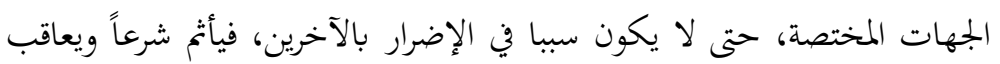
قانوناً.

\section{ثانيًا: التوصيات}

1- جمع الأحكام الشرعية الطبية المتعلقة بالأوبئة، في موسوعة علمية، حتى تكون مرجعاً في بابها.

2- التعاون بين الدول في مواجهة الأوبئة، وذلك بتوحيد الأنظمة والإجراءات لمكافحة الأمراض والأوبئة المعدية. 3- إضافة القضايا الطبية الشرعية للمناهج في الكليات الشرعية والطبية، مثل

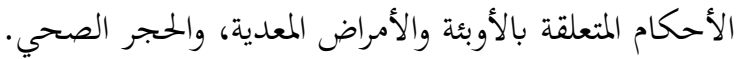
4- تحديد جهة متخصصة في تحديد الغرامات على المخالفين للقرارات الاحترازية

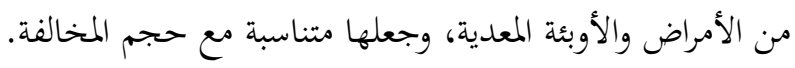

\section{فهرس المصادر والمراجع}

ابن الأثير، مجد الدين أبو السعادات، النهاية في غريب الحديث، تحقيق: طاهر أحمد الزاوي،

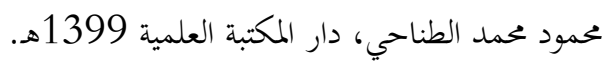

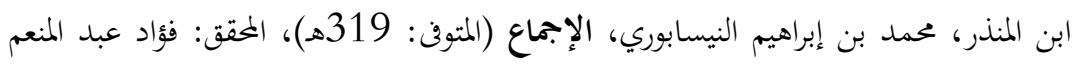

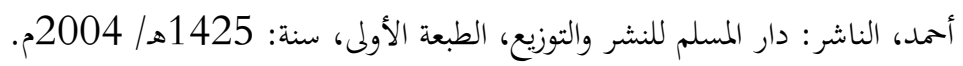

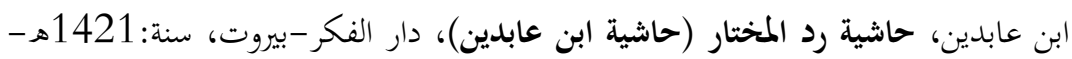
2000 
ابن عاشور، محمد الطاهر، مقاصد الشريعة الإسلامية، المحقق: محمد الحبيب ابن الخوجة،

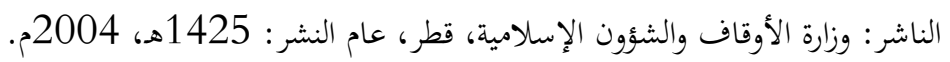

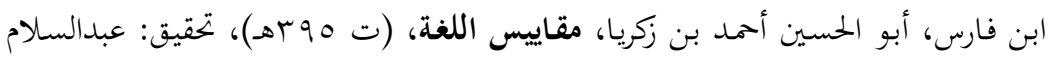

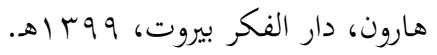
ابن قدامة، المقدسي، المقنع في فقه الإمام أحم، دار الكتب العلمية-بيروت، الطبعة الأولى،

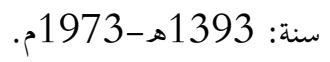

ابن كثير، البداية والنهاية، تحقيق: علي الشيري، الناشر: دار إحياء التراث العربي، الطبعة الأولى

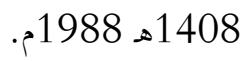
ابن نجيم، الأشباه والنظائر، الناشر: دار الكتب العلمية، بيروت، لبنان، الطبعة: الأولى،

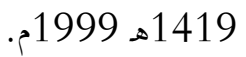
الأزهري، أبو منصور محمد بن أحمد، تمذيب اللغة، (ت · • آهـ)، تحقيق: إبراهيم الأبياري،

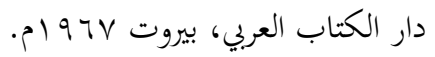
الآمدي، علي، الإحكام في أصول الأحكام، (ت آسآهـ)، تحقيق: سيد الجميلي، دار

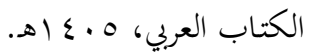

الكلوذاني، الخطاب محفوظ بن أحمد، الانتصار في المسائل الكبار، (ت . 10هـ)، تحقيق :د.

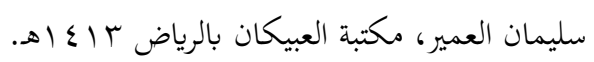

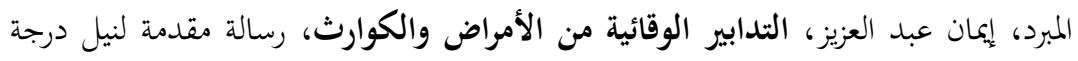

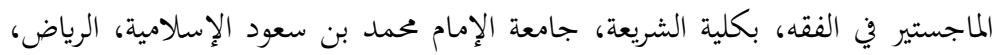
1432-1433هـ.

بكراوي، محمد عبد الحق، التكاليف الشرعية في زمن كورونا بين الرخصة والعزيمة، المؤتمر الدولي التاسع الذي نظمه مركز لندن للبحوث والاستشارات بالتعاون مع مركز يونيفرسال

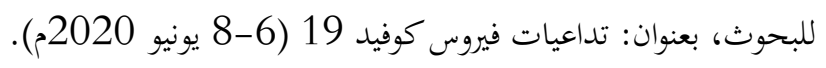
الثبيتي، علي بن جابر، الوقاية الصحية في الإسلام، مجلة البحوث الإسلامية، العدد الواحد

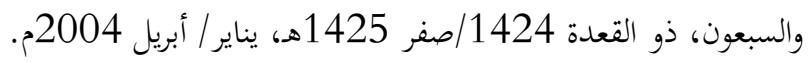


ابن رجب، عبد الرحمن بن أحمد السَلامي، جامع العلوم والحكم في شرح خمسين حديثا من

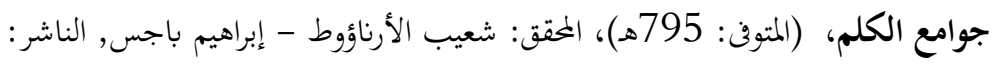

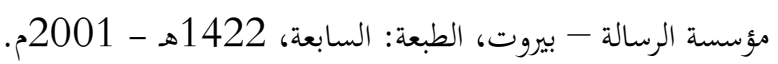

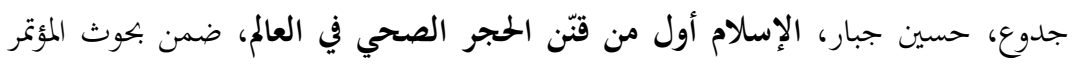
الدولي التاسع ا(تداعيات فيروس كوفيد 19،بار، الإسلاحم الذي نظمه مركز لندن للبحوث

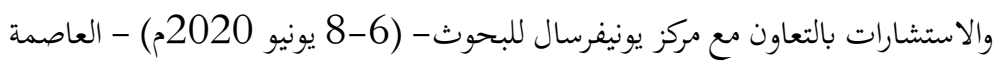

$$
\text { البريطانية لندن 2020م. }
$$

جعلوط، عامر محمد نزار، فقه الأوبئة، بيان لأهم الأحكام الشرعية المتعلقة بأزمة (كوفيد 19)

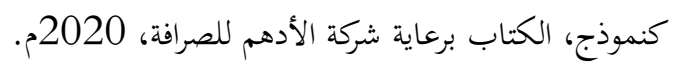

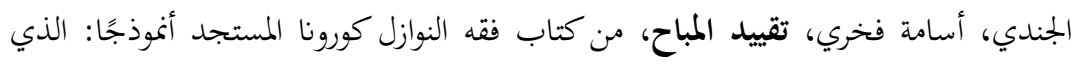

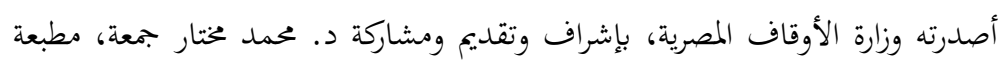

$$
\text { وزارة الأوقاف 1441هـ وزارة الاوقاف المصرية، 2020م. }
$$

الجوهري، إسماعيل بن حماد، الصحاح، تحقيق: أحمد عبد الغفور عطار ط:2 دار العلم للملايين،

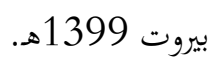

جولدن صاري يلدز، الحجر الصحي في الحجاز، ترجمة الدكتور : عبد الرازق بركات، طبعة المركز

$$
\text { فيصل للبحوث والدراسات الإسلامية سنة 2001م. }
$$

الخرشي، محمد بن عبد الله، شرح مختصر خليل (المتوفى: 1101هـ)، الناشر: دار الفكر للطباعة الإسية

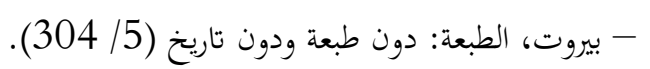

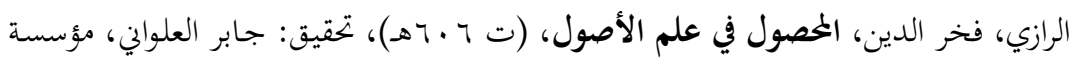

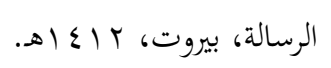

رضا، صالح أحمد، الإعجاز العلمي في السنة النبوية، مكتبة العبيكان-الرياض، الطبعة الأولى،

$$
\text { سنة: 1421هـ- 2001م. }
$$

روح وريحان، من منشورات جامعة محمد بن زايد للعلوم الإنسانية، أبو ظبي، الطبعة الأولى، سنة:

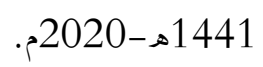


الزحيلي، محمد مصطفى، القواعد الفقهية وتطبيقاتما في المذاهب الأربعة، الناشر: دار الفكر،

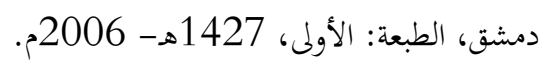

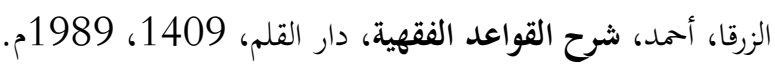

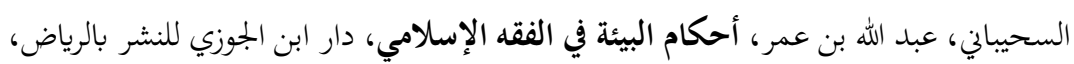
.8 . $\leqslant Y q$

السرخسي، محمد بن أحمد بن أبي سهل شمس الأئمة، المبسوط، الناشر: دار المعرفة، بيروت،

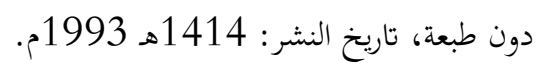

سليمان، هند الزبير بابكر، الطب الوقائي في السنة النبوية، بحث مقدم إلى جامعة الخرطوم

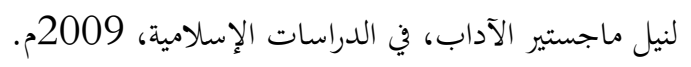

سنن ابن ماجه: ابن ماجه أبو عبد الله محمد بن يزيد القزويني، وماجه اسم أبيه يزيد (المتوفي:

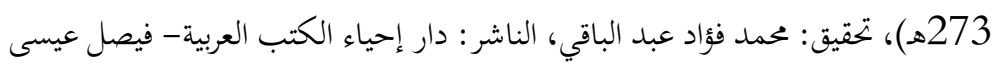

$$
\text { البابي الحلبي. }
$$

سنن ابي داود: أبو داود سليمان بن الأشعث بن إسحاق بن بشير بن شداد بن عمرو الأزدي

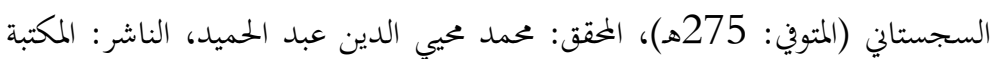

$$
\text { العصرية، صيدا، بيروت. }
$$

السيوطي، الأشباه والنظائر، الناشر: دار الكتب العلمية، الطبعة الأولى، 1411هـ 1990م. 1990.

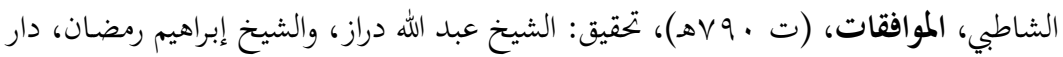

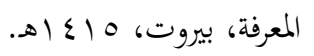

الشربيني، محمد الخطيب، تحفة الحختاج، دار الكتب العلمية-بيروت، الطبعة الأولى، 1994م.

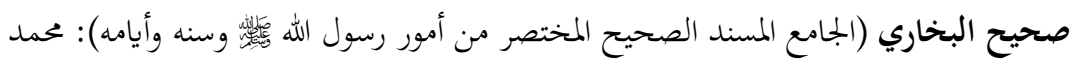

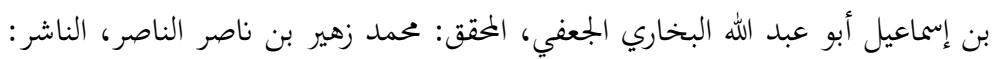
دار طوق النجاة (مصورة عن السلطانية بإضافة ترقيم محمد فؤاد عبد الباقي)، الطبعة:

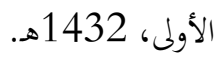


صحيح مسلم: مسلم بن الحجاج أبو الحسن القشيري النيسابوري (المتوفن: 261هـ)، المحقق:

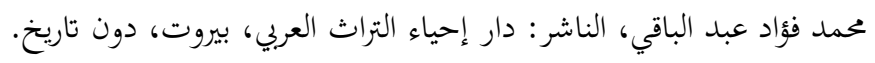
الظاهري، ابن حزم، المحلى بالآثار، دار الفكر-بيروت.

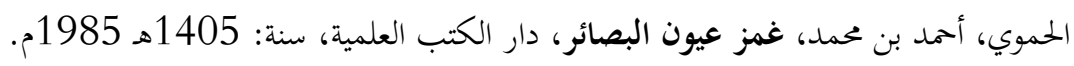

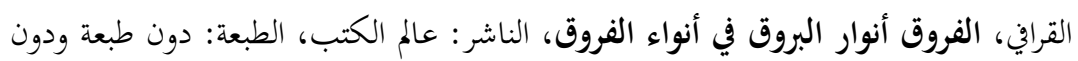
تاريخ. القسطلاني، أحمد بن محمد بن أبي بكر بن عبد الملك القتبي المصري، إرشاد الساري شرح

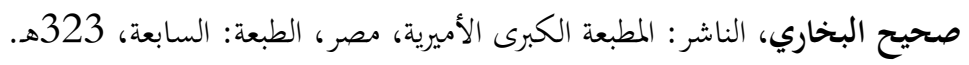

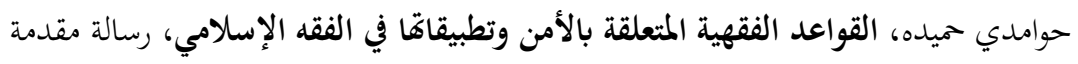

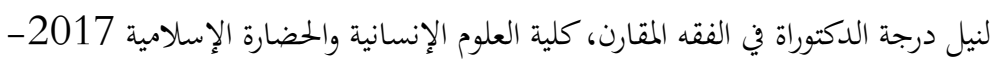
2018

كنعان، أحمد، الموسوعة الطبية الفقهية، الناشر: دار النفائس للنشر والتوزيع 2007م.

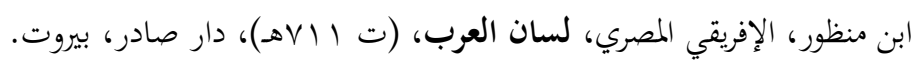

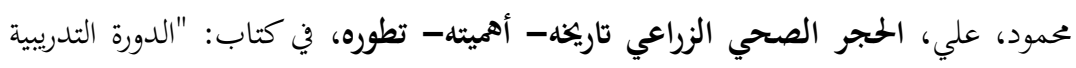

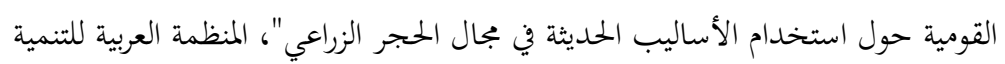

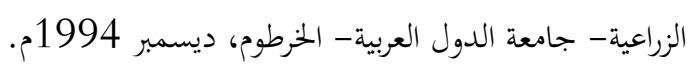

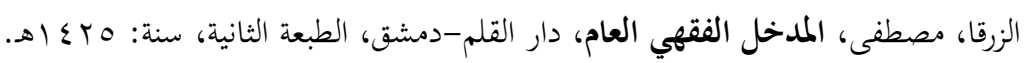

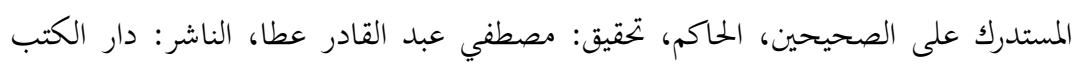

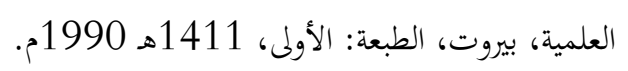

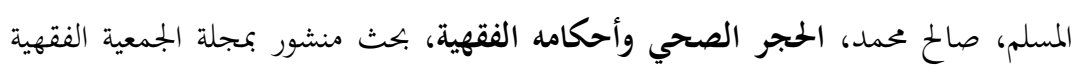

$$
\text { السعودية، العدد الخمسون 2020م، الحجر الصدي وأحكامه }
$$

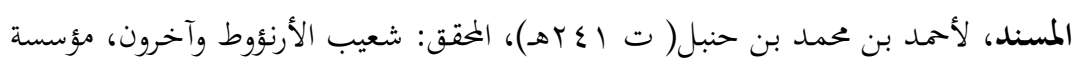

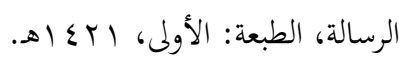


مشخص وآخرون، أمين عبد الحميد، الأمراض المعدية ومستجداته العالمية، أعد بالتعاون بين

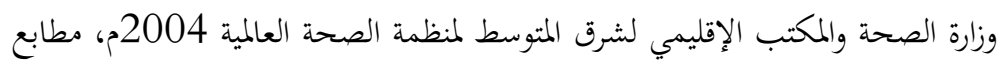
دار الهلال الرياض. المعجم الكبير للإمام الطبراني، المحقق: حمدي بن عبد المجيد السلفي، دار النشر: مكتبة ابن تيمية، القاهرة، الطبعة: الثانية. مجمع اللغة العربية بالقاهرة، المعجم الوجيز، الهيئة العامة لشؤون المطابع الأميرية بالقاهرة، . . . 1p المنظمة العربية للتنمية الزراعية، واقع الحجر الزراعي في الأقطار العربية، في كتاب "دراسة حصر

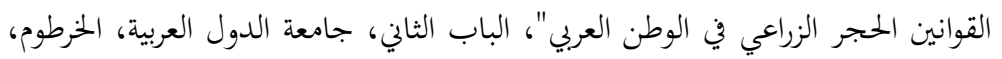
ديسمبر 1994م.

موسى، أشرف فهمي، الحجر الصحي والعزل المنزلي في ضوء الشريعة وموقفنا منه، ضمن

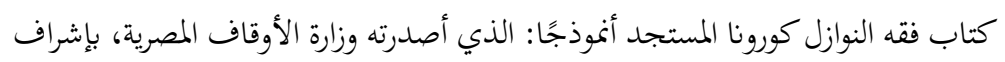

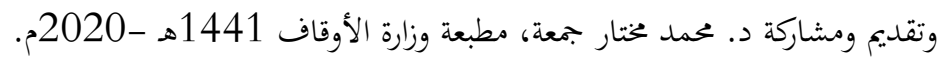

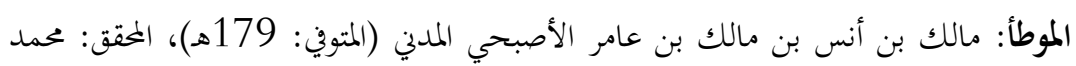

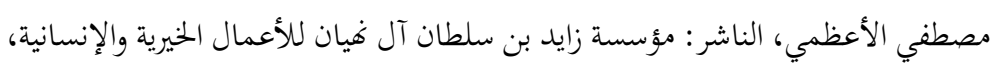

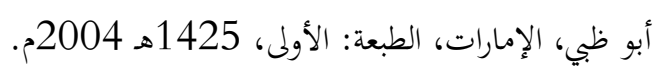

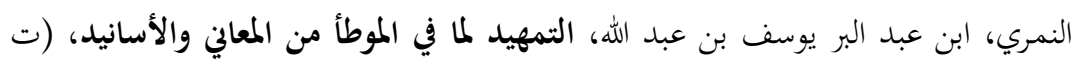

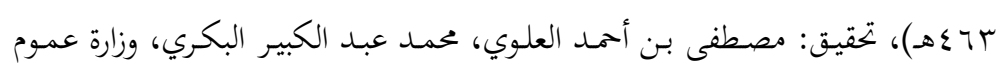

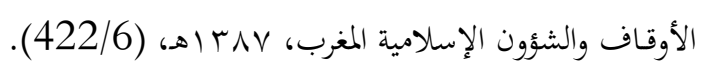

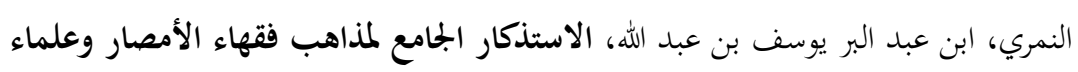

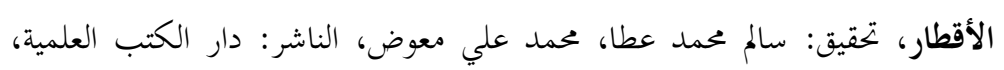

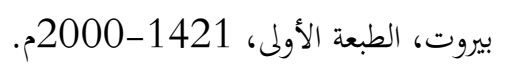

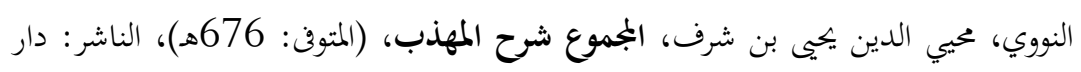
الفكر، (طبعة كاملة معها تكملة السبكي والمطيعي). 
النووي، عحي الدين يهيى بن شرف، المنهاج شح صحيح مسلم بن الحجاج، (المتوفن:

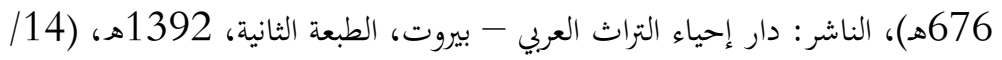

البورنو، الوجيز في إيضاح قواعد الفقه الكلية، الناشر: مؤسسة الرسالة العلمية، الطبعة الرابعة 1416هـ، 1996م.

الوشلي، عبد قاسم، التوجيه التشريعي الإسلامي في نظافة البيئة وصحتها، مجلة جامعة أم

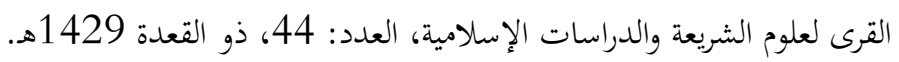

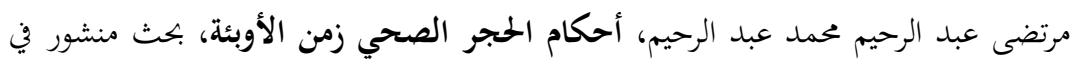

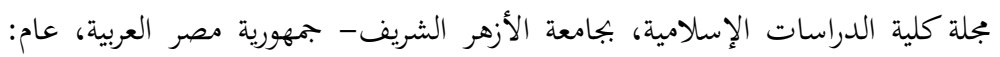
2020

العقلا، غادة بنت محمد بن علي، الحجر الصحي بين الضرورة والآثار، بحث منشور في مجلة

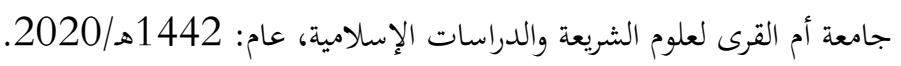

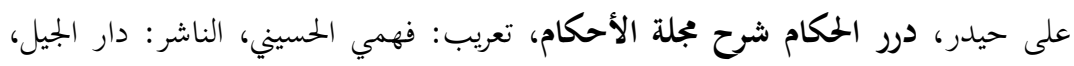

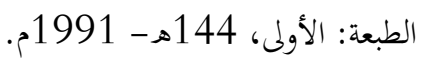

\section{References:}

Abū dāwūd slīmān bn al-' ash 'th bn isḥāq bn bshīr bn shdād bn 'mrū al-'azdī al-sjstānī (ālmtūfì: 275h.), snn abī dāūd, al-muhaqiq: muḥammad mḥyi al-dīn 'abd al-ḥamīd, al-nāshr: al-mktbah al'șrīah, șīdā, bīrūt.

Al-'ām.dī, '1.ī, al-ị̣kām fī aṣūl al-'ạ̣k.ām, (t 631h..), taḥqīq s.īd aljmīl.ī, dār al-kt.āb al- 'rbī, 1405h..

Al-'azharī, abū manșūr muḥammad bn aḥmad , tahd̄īb al-lg̈hah, ( $\mathrm{t}$ 370h.), taḥqīq ib.rāhīm al-'abī.ārī, dār al-ktāb al- 'rb̄̄i, bīrūt $1967 \mathrm{~m}$.

Al-bukh̄ārī, muḥammad ibn ismā 'îl abū 'abd al-lh al-j' fì, al-muhaqiq: muḥammad zhīr bn nāṣr al-nāṣr, șhịḥ al-bkḥaārī (āljām ' al-msnd al-ṣ̣ịh al-mkhnatșr mn amūr rsūl al-lh șli al-lh 'īh ūslm ūsnh ū' aīāmh), al-nāshr: dār țaūq al-njāah (mṣūrah 'n al-slțaānīah 


$$
\text { التأصيل الشرعي لسلطة ولي الأمر في الإلزام بالحجر الصحي }
$$

biḍāfah trqīm muḥammad fu'ād 'abd al-bāqī), al-țab 'ah: al-'aūli, 1432h..

Al-būrnū, al-ūjīz fì ị̣āḥ qwā'd al-fqh al-klīah, al-nāshr: mu'ssah alrsālah al- 'Imīah, al-țab 'ah al-rāb' ah 1416h., 1996m.

Al-ḥākm, al-mstdrk 'li al-ṣ̣īḥīn, , taḥqīq: mșțafî 'abd al-qādr 'ṭaā, alnāshr: dār al-ktb al-'lmīah, bīrūt, al-ṭab 'ah: al-'aūli, $1411 \mathrm{~h}$. 1990m.

Al-ḥamawy, aḥmad bn muḥammad, g̉hmz 'īūn al-bṣā' ir, dār al-ktb al'Imīah, snah: 1405h. 1985m.

Al-jindī, asāmah fkharī, tqyid al-mbāḥ, mn ktāb fqh al-nwāzl kūrūnā al-mstjd anmūḍj̄â: al-d̄ī aṣdrth ūzārah al-'aūqāf al-mṣrīah, bishrāf ūtqdīm ūmshārkah d. Muhammad mkhatār jm'ah, mtab 'ah ūzārah al-'aūqāf 1441h. 2020m.

Al-jūharī, ismā' îl bn ḥmād, al-ṣhạḥ, taḥqīq: aḥmad 'abd al-ghhfūr 'ṭaār ța:2 dār al-' lm llmlāyin, bīrūt 1399h. .

Al-kharshī, muhammad bn 'abd al-lh, shrḥ mkhatṣr khalīl (d.: 1101h.), al-nāshr: dār al-fkr llțabā'ah - bīrūt, al-ṭab 'ah: bdūn țab 'ah ūbdūn tārīkha.(304 /5)

al-klūdān̄ī, al-kh̄ațaāb mḥfūẓ bn aḥmad , al-āntșār fì al-msā' il al-kbār, (t 510h.), tḥqī.q: d. Slīmān al-'mīr, mktbah al- 'bīkān bālrīạḍ 1413h..

Al-mubarrid, īmān 'abd al-'zīz, al-tdābīr al-ūqâ' 'iah mn al-'amrāọ wālkwārth, rsālah mqdmah lnīl drjah al-mājstīr fì al-fqh, bklīah al-shrīah, jām 'ah al-imām muḥammad bn s'ūd al-islāmīah, alrīāẹ, 1432-1433h..

Al-munaẓamah al-' rabīyyah lltnmīah al-zrā' 'īah, wāq' al-hj̣ al-zrā' '⿳亠 fì al-'aqțaār al-' rbīah, fĩ ktāb "drāsah ḥṣr al-qwānīn al-ḥjr al-zrā 'ī fĩ al-ūṭan al-'rbīi", al-bāb al-thānī, jām 'ah al-dūl al-'rbīah, alkharțaūm, dīsmbr 1994m.

Al-muslim, șālḥ muḥammad , al-ḥjr al-ṣ̣̣̂̄ ù' ạ̣kāmh al-fqhīah, bḥth mnshūr bmjlah al-jm'īah al-fqhīah al-s'ūdīah, al-'dd alkhamsūn 2020m.

Al-namrī, ibn 'abd al-br īūsf bn 'abd al-lh, al-tmhīd lmā fĩ al-mūța'a mn al-m 'ān̄̄ wāl' asānīd, (t 463h..), tḥqī..q: mṣ..țafi b..n ạ̣m..d 
al-'1..wy , muḥammad 'b..d al-kbī..r al-bkrī, ūzārah 'm..ūm al'aūq..āf wālshu' ūn al-islāmīah al-mg̉hrb, 1387h.(422/6) ,.

Al-nawawī, muḥyi al-dīn īḥìi bn shrf, al-mjmū' shrḥ al-mhḍb, (d.:

676h.), al-nāshr: dār al-fkr, (țab 'ah kāmlah m 'hā tkmlah al-sbkī wālmțaî'î̀).

Al-nawawī, muḥyi al-dīn ịhịi bn shrf, al-mnhāj shrḥ ṣ̣ịḥ muslim bn al-ḥjāj, (d.: 676h.), al-nāshr: dār iḥīà' al-trāth al-'rb̄̄ - bīrūt, alțab'ah: al-thānīah, 1392h.(173/14),

Al-nimrī, ibn 'abd al-br īūsf bn 'abdāllh, al-āstḍkār al-jām' lmḍāhb fqhā' al-' amșār ū 'lmā' al-' aqțaār, taḥqīq: sālm muḥammad 'țaā, muḥammad 'lī m'ūẹ, al-nāshr: dār al-ktb al-'lmīah, bīrūt, alțab 'ah: al-'aūli, 1421-2000m.

Al-qarāfī, al-frūq anwār al-brūq fì anwā' al-frūq, al-nāshr: 'ālm al-ktb, al-țab 'ah: bdūn țab ah ūbdūn tārīkhna.

Al-qasțalānī, aḥmad bn muḥammad ibn abī bkr bn 'abd al-mlk al-qtībī al-mṣrī, irshād al-sārī shrḥ ș̣̣̄ị al-bkḥaārī, al-nāshr: al-mṭab 'ah al-kbri al-'amīrīah, mṣr, al-țab 'ah: al-sāb 'ah, 323h..

Al-'qlā, ghādah bnt muḥammad bn 'līe al-ḥajr al-ṣ̣ị bīn al-ḍrūrah wāl'āthār, bḥth mnshūr fī mjlah jām'ah am al-qri l'lūm alshrī'ah wāldrāsāt al-islāmīah, 'ām: 1442h./2020.

Al-rāzī, fkh̄ar al-dīn, al-mḥṣūl fī 'lm al-'așūl, (t 606h..), taḥqīqj jābr al'l.wānī, mu' ss.ah al-rsālah, bīrūt, 1412h..

Al-sarkhnasī, muḥammad ibn aḥmad bn abī shl shms al-'a'imah, almbsūṭa, al-nāshr: dār al-m'rfah, bīrūt, al-țab 'ah: bdūn țab'ah, tārīkha al-nshr: 1414h. 1993m.

Al-shāțabī, al-muwāfqāt, (t 790h.), taḥqīq al-shīkhnaān 'abd al-lh drāz wib.rāhīm rmụ.ān, dār al-m 'rfah, bīrūt, $1415 \mathrm{~h}$..

Al-sḥībānī, 'abd al-lh bn 'mr, aḥkām al-bī' iah fĩ al-fqh al-islāmī, dār ibn al-jūzī lil nashr, Riyadh 1429h..

Al-shirbīnī, muḥammad al-kḥațaīb, tḥ̂ah al-mḥtāj, dār al-ktb al'Imīah-bīrūt, al-first edition, snah:1415h-1994m.

Al-sīyūṭā̄, al-' ashbāh wālnẓā' ir, al-nāshr: dār al-ktb al-'lmīah, alțab 'ah: al-'aūli, 1411h. 1990m.

Al-ṭabrānī, al-m 'jm al-kbīr, al-muḥaqiq: ḥmdī bn 'abd al-mjīd al-slfì, dār al-nshr: mktbah ibn tīmīah, al-qāhrah, al-țab 'ah: al-thānīah. 
التأصيل الشرعي لسلطة ولي الأمر في الإلزام بالحجر الصحي

Al-thubaitī, 'alī bn jābr, al-ūqāīah al-ṣ̣īah fĩ al-islām, mjlah al-bḥūth al-islāmīah, al-'dd al-wāḥd wālsb ūn, doū al-q'dah 1424/ṣfr 1425h., īnāir/ abrīl 2004m.

Al-washlī, 'abd qāsm, al-tūjīin al-tshrī'ì al-islāmī fī nẓāfah al-bīi iah ūṣhthā, mjlah jām'ah am al-qri l'lūm al-shrī'ah wāldrāsāt alislāmīah, issse: 44, dhul-qi 'dah 1429h..

Al-ẓāhrī, ibn ḥazm, al-muḥla bāl' āthār, dār al-fkr-bīrūt.

Al-zarqā, aḥmad, sharḥ al-qwā' d al-fqhīah, dār al-qlm, snah al-nshr: 1409, 1989m.

Al-zarqā, mștafi, al-mdkh̄al al-fqhī al-'ām, dār al-qlm-dmshq, alțab ah al-thānīah, snah: $1425 \mathrm{~h}$.

Al-zuhị̂lī, muḥammad mștafi, al-qwā'd al-fqhīah ūttabīqāthā fì almd̄āhb al-' arb 'ah, al-nāshr: dār al-fkr, dmshq, al-țab 'ah: al-'aūli, 1427h.- 2006m.

Bakrāwy, muḥammad 'abd al-ḥq, al-tkālīf al-shr' īah fĩ zmn kūrūnā bīn al-rkhașah wāl 'zīmah, al-mu'tmr al-dūlī al-tās' al-d̄i nẓmh mrkz lndn llbḥūth wālāstshārāt bālt'āūn m mrkz īūnīfrsāl llbhūth, b nwān: tdā îât fî̀ūs kūfîd 19 (6-8 īūnīū 2020m).

Gūldin șārī īldz, al-hjjr al-ṣhị fì al-ḥjāz, trjmah al-dktūr: 'abd al-rāzq brkāt, țab 'ah al-mrkz fiṣl llbhūth wāldrāsāt al-islāmīah snah $2001 \mathrm{~m}$.

Ḥawāmdī ḥmīdh, al-qwā' d al-fqhīah al-mt 'lqah bāl' amn ūtțabīqāthā fì al-fqh al-islāmī, rsālah mqdmah lnīl drjah al-dktūrāh fĩ al-fqh almqārn, klīah al-' lūm al-insānīah wālḥ̣āarah al-islāmīah 20172018m.

Ibn 'ābidīn, hạāhīah rd al-mkhatār (hāshyah ibn 'ābdīn), dār al-fikrbīrūt 1421-2000

Ibn al-'athīr, mjd al-dīn abū al-s'ādāt, al-nhāīah fī ghrīb al-ḥdīth, taḥqīq: țaāhr aḥmad al-zāwy, maḥmūd muḥammad al-ṭaanāḥ̄, dār al-maktabah al-' lmiyyah 1399.

Ibn al-mundhir, muḥammad ibn ibrāhīm al-nīsābūrī, al-ijmā' (d. 319h.), al-muḥaqiq: fu' ād 'abd al-mun 'im aḥmad, al-nāshr: dār al-muslim lil nashr wāl tawzī' , first edition, 1425h./ 2004m. 
Ibn 'āshūr, muhạmmad al-ṭaāhr, mqāṣd al-shrī'ah al-islāmīah, almuḥaqiq: muḥammad al-ḥabīb ibn al-khnaūjah, al-nāshr: wizārah al-'aūqāf wālshu'ūn al-istāmīah, qațar, 1425h., 2004m.

ibn fāris, abū al-ḥs.īn aḥm.d b.n zkrī.ā, mq.āyis al-lg̀h.ah, (t 395h..), tḥqī.q: 'abdāls.lām hārūn, dār al-fikr bīrūt, 1399h..

Ibn ḥanbal, l' ạ̣m.d b.n mḥm.d)t 241h..), al-ms.nd, al-mḥq.q: sh. 'ỉb al'arn.u'ūṭa ū'ākhha.rūn, mu'ssah al-rsālah, al-țab'ah: al-'aūli, 1421h..

Ibn kathīr, al-bdāyah wālnhāīah, taḥqīq: 'lī al-shīrī, al-nāshr: dār iḥīà' al-trāth al-'rbī, al-țab 'ah: al-'aūli 1408h. 1988m.

Ibn mājh abū 'abd al-lh muḥammad ibn īzīd al-qzwynī, (ālmtūfì: 273h.), snn ibn mājh taḥqīq: muhammad fu' ād 'abd al-bāqī, alnāshr: dār iḥīà' al-ktb al- 'rbīah- fịṣl 'īsi al-bābī al-ḥalbī.

Ibn manẓūr, al-ifrīqī, lisān al-'arab, (t 711h.), dār șādr, bīrūt.

Ibn nujaym, al-' ashbāh wālnẓā' ir, al-nāshr: dār al-ktb al-' lmīah, bīrūt, lebanon, al-țab 'ah: al-'aūli, 1419h. 1999m.

Ibn qudāmah, al-mqds̄̄, al-mqn' fĩ fqh al-imām aḥmad, dār al-ktb al'lmīah-bīrūt, al-first edition, snah: 1393h-1973m.

Ibn rajab, 'abd al-rḥmn bn aḥmad al-salāmī, jām' al- 'lūm wālḥkm fī shrḥ khamsīn ḥdīthā mn jwām 'al-klm, (d.: 795h.), al-muḥaqiq: sh 'īb al-' arnāu' ūṭa - ibrāhīm bājs, al-nāshr: mu'ssah al-rsālahbīrūt, al-țab 'ah: al-sāb 'ah, 1422h. - 2001m.

Jaddū', ḥsīn jbār, al-islām aūl mn qnn al-ḥjr al-ṣ̣ị̄ fī al-'ālm, ḍmn bhūth al-mu'tmr al-dūlī al-tās " «tdā'iât fìrūs kūfìd 19», al-d̄i nẓmh mrkz lndn llbḥūth wālāstshārāt bālt 'āūn m ' mrkz īūnīfrsāl llbḥūth- (6-8 īūnīū 2020m)- al-'āṣmah al-brīṭaānīah lndn 2020m.

Ja 'lūṭ, 'āmir muhammad nzār, fqh al-'aūb'iah, bīān l'ahm al-'aḥkām al-shr' īah al-mt' lqah b' azmah (kūfīd19) knmūḍj, al-ktāb br' āīah shrkah al-'adhm llșrāfah, 2020m.

Kan 'ān, ạ̣mad , al-mūsū 'ah al-țabīah al-fqhīah, al-nāshr: dār al-nfầ' is lil nashr wāltūzī‘ $2007 \mathrm{~m}$.

Maḥmūd, 'lāi, al-ḥajr al-ṣiḥ̄ al-zrāēi tārīkḥah- ahmīth- tṭaūrh, fĩ ktāb "āldūrah al-tdrībīah al-qūmīah hụul astkḥadām al-'asālīb al- 
ḥdīthah fì mjāl al-ḥjr al-zrā 'ī", al-mnẓmah al- 'rbīah lltnmīah alzrā'īah- jām 'ah al-dūl al-'rbīah- al-kharțaūm, dīsmbr 1994m.

Mu'jam ' al-lg̀hah al-'rbīah bālqāhrah, al-m 'jm al-ūjīz, al-hī’iah al'āmah lshu' ūn al-mțāà ' al-'amīrī.ah bālq.āhrah, m2001.

Murtaḍa 'abd al-raḥīm muḥammad 'abd al-rḥīm, aḥkām al-ḥjr al-ṣhị zmn al-'aūb'iah, bḥth mnshūr fī mjlah klīah al-drāsāt alislāmīah, bjām 'ah al-' azhr al-shrīf- jmhūrīah mṣr al-'rbīah, 'ām: 2020m.

Mūsa, ashrf fhmīe al-ḥjr al-ṣhī wāl'zl al-mnzlī fì ḍu' al-shrī'ah ūmūqfnā mnh, ḍmn ktāb fqh al-nwāzl kūrūnā al-mstjd anmūdjjā: al-d̄ī aṣdrth ūzārah al-'aūqāf al-mṣrīah, bishrāf ūtqdīm ūmshārkah d. Muhammad mkḥatār jm'ah, mțab'ah ūzārah al-'aūqāf 1441h. -2020m.

Mushkhaș ù ākhnarūn, amīn 'abd al-ḥmīd, al-'amrāọ al-m' dīah ūmstjdāth al-'ālmīah, a d bālt' āūn bīn ūzārah al-ṣhah wālmktb al-iqlīmī lshrq al-mtūsṭa lmnẓmah al-ṣ̣hah al-'ālmīah 2004m, mțaāb' dār al-hlāl al-rīạḍ.

Muslim bn al-ḥjāj abū al-ḥsn al-qshīrī al-n̄isābūrī (ālmtūfì: 261h.), șahịḥ muslim al-muḥaqiq: muḥammad fu' ād 'abd al-bāqī, alnāshr: dār iḥ̄īà al-trāth al- 'rbī, bīrūt, bdūn tārīkhِa.

Riḍā, șāliḥ aḥmad, al-i' jāz al-' lmī fĩ al-snah al-nbwyah, maktbah al'bīkān-ālrīâd, al-first edition,1421h-2001m.

Rūḥ wa rayḥān, min mnshūrāt jām 'ah muḥammad bn zāīd ll' lūm alinsānīah, abūẓbī, al-first edition, 1441h-2020m.

Sulaimān, hind al-zubīr bābkr, al-ṭab al-ūqā'î fĩ al-snah al-nbwyah, bḥth mqdm ila jām 'ah al-kḥarțaūm lnīl mājstīr al-'ādāb, fî aldrāsāt al-istāmīah, 2009m. 